\title{
Developing Digital Economy and Society in the Light of the Issue of Digital Convergence of the Markets in the European Union Countries
}

\author{
Ryszard Borowiecki $^{1}$, Barbara Siuta-Tokarska ${ }^{2}{ }^{\mathbb{D}}$, Jolanta Maroń ${ }^{3}$, Marcin Suder ${ }^{4} \mathbb{D}$, Agnieszka Thier $^{2}$ \\ and Katarzyna Żmija 2,*(D)
}

\section{check for}

updates

Citation: Borowiecki, R.;

Siuta-Tokarska, B.; Maroń, J.; Suder,

M.; Thier, A.; Żmija, K. Developing

Digital Economy and Society in the

Light of the Issue of Digital

Convergence of the Markets in the European Union Countries. Energies 2021, 14, 2717. https://doi.org/ 10.3390/en14092717

Academic Editor:

Radoslaw Miskiewicz

Received: 24 March 2021

Accepted: 5 May 2021

Published: 10 May 2021

Publisher's Note: MDPI stays neutral with regard to jurisdictional claims in published maps and institutional affiliations.

Copyright: (c) 2021 by the authors. Licensee MDPI, Basel, Switzerland. This article is an open access article distributed under the terms and conditions of the Creative Commons Attribution (CC BY) license (https:// creativecommons.org/licenses/by/ $4.0 /)$.
1 WSB University in Dąbrowa Górnicza, 41-300 Dąbrowa Górnicza, Poland; borowier@uek.krakow.pl

2 Department of Economics and Organization of Enterprises, Institute of Management, Cracow University of Economics, 31-510 Krakow, Poland; siutab@uek.krakow.pl (B.S.-T.); thiera@uek.krakow.pl (A.T.)

3 Department of International Management, Institute of Management, Cracow University of Economics, 31-510 Krakow, Poland; zajacjol@uek.krakow.pl

4 Department of Applications of Mathematics in Economics, Faculty of Management, AGH University of Science and Technology, 30-067 Krakow, Poland; msuder@agh.edu.pl

* Correspondence: zmijak@uek.krakow.pl

\begin{abstract}
The main objective of the paper is to present the development of digital economy and society in the Countries of the European Union in the light of the digital convergence of these markets. The analysis was based on the data on the Digital Economy and Society Index (DESI) from 2015 and 2020. Empirical studies have been conducted in two stages. First, basic measures of time series dynamics were used to determine the dynamics of changes in index values. On the other hand, in order to classify countries in terms of similarity of value and structure of the DESI, a cluster analysis was used as one of the basic methods of the so-called unsupervised statistical grouping. The studies presented confirm that the levels of indicators and the dynamics of changes in their value at the level of the synthetic DESI indicator, and in the five underlying areas of analysis, vary despite the fact that almost all are pro-growth, including for isolated clusters of EU-28 countries. When analyzing the DESI synthetic index and its components, it was concluded that there is generally an increase in convergence between the EU-28 countries in terms of the level of development of the digital economy and society, as well as in four components: Connectivity, Human Capital, Use of Internet Services and Digital Public Services. The Integration of Digital Technology area was the only one where increasing polarization of results was observed. The added value of the paper is to fill the research gap in research on the digital convergence of markets in the Countries of the European Union.
\end{abstract}

Keywords: convergence; digitalization; clusters; DESI

\section{Introduction}

The economy and the digital society are terms that are part of the European Union's 'Europe 2020' strategy. This strategy is based on the pursuit of competitiveness and full employment in the EU economy in a spirit of sustainability, as values ensuring equality of intergenerational opportunities [1-5]. The development of such an economy and society is, in the twenty-first century, indicated as the foundation of growth. The information and communication technology (ICT) sector, which importance for development processes is expressed in its dynamic growth, plays a particular role in this regard, making it a significant driver of economic, social and even civilizational progress, as some authors point out [6-8]. There is evidence that ICT positively affects the economy and social welfare in several dimensions. It supports new types of interactions, services and business practices [9-13], accelerates the progress of various transactions, allows barriers to market access to be overcome, eliminates spatial constraint, creates alternative commercial platforms and new 
industries that generate new employment opportunities [14-16]. It changes the way people interact with each other and obtain information [17]. Empirical studies show that today the difference in countries' economic performances and their global competitiveness greatly depends on the level of acceptance, availability, and use of ICT [18-21]. However, the development of ICT may create a digital divide between countries, regions, households, individuals and companies in terms of access to and use of ICT [22]. To achieve benefits from ICT, certain obstacles need to be overcome, especially inequalities both among and within countries regarding the access to these technologies and the ability to use them [23]. However, it should be stressed that, taking into account the multidisciplinary nature of ICT for development research, various theoretical paths have been explored to investigate the adoption, use and impact of ICT in world's societies. Many various forms of ICT applications and their contextual use and subsequent socio-economic impacts have been monitored by researchers from information systems (IS), development economics, social science and consumer studies over the years However, skepticism regarding the success of ICT-led initiatives and concerns regarding their actual and potential challenges have also been discussed in academic literature [24-31]. It is, therefore, recognized that this subject is an important aspect of current management practice, while at the same time research related to the broadly understood development of the economy and societies in the twenty-first century.

Considering the importance that the European Union gives to a harmonious digital development among all of its member states, the key issue is to assess how the situation evolves in particular EU countries. The current research helps to achieve this and sheds light on the issue of digital convergence. The authors intend to provide a complete and updated analysis of the development of digital economy and society within the 28 Member States of the European Union (EU-28) (The study included the United Kingdom, which is no longer a member of the European Union. However, the DESI published in a given year is to a large extent calculated on the basis of partial indicators relating to the previous calendar year. Therefore, due to the fact that the DESI 2020 value includes data from 2019, the analyzes also took into account the United Kingdom, and the average values were calculated for $28 \mathrm{Member}$ States.). The main objective of the paper is, to present the development of the digital economy and society in the Countries of the European Union in the light of the digital convergence of these markets. For analytical purposes, the objective of empirical research is also defined, which is to identify and exemplify changes in cluster structures in the digital economy and society index in the period 2015-2020 in the context of the development of the digital economy and society in the EU-28. The interest of the authors in this subject is related to the challenges and dilemmas that are emerging regarding changes in economies and societies in the context of the progressive transition from an industrial-based economy to an economy based on digital products and services, relating to data, information and, finally, knowledge, which are decisive for achieving and maintaining a certain competitive position.

The work formulated research hypotheses, including the main hypothesis and two specific hypotheses. The main hypothesis is that "in the EU-28 countries, the development of the digital economy and society is visible in 2015-2020". On the other hand, the specific hypotheses are as follows:

HS1: The development of the digital economy and society of the Countries of the European Union is not homogeneous and specific groups of countries (clusters) are distinguished taking into account the similarity of their performance in this area;

HS2: The levels of indicators and the dynamics of their value changes over the period 2015-2020 in the five underlying areas of DESI analysis, i.e., connectivity, human capital, use of internet services, integration of digital technology, and digital public services which are diverse, although they are all pro-growth in nature, also for the clusters/groups of EU-28 countries studied. Their rate of change is not even.

The added value of the research is closing the research gap related to the identification of similarities (cluster grouping) among EU countries in their levelof development of the 
digital economy and society. This work will also answer the question of whether the EU-28 countries are on the path towards digital convergence. Filling this gap should help to capture the overall picture of the results achieved by the countries of the community: their nature (pro-growth/ pro-fall/unspecified), the dynamics of change, and it may constitute the basis for the policies formulated, taking into account individual countries and their groups (clusters), in order to increase the chances of "catching up" among those countries with similarities with the lowest values of structures in DESI. The concept of the Digital Single Market means not only creating a framework but ensuring the most uniform possible conditions (legal, economic, technological, including infrastructure) and opportunities for the development of the digital economy and society in the context of the European Union as a whole. Filling this gap can be seen, therefore, as a contribution to a change in the perception of the "philosophy" of the creation of the European Union's policy from the current one, aimed de facto at reducing polarization between countries (the context of divergence) in order to increase the similarity in the levels of development of economies and digital society (convergence), leading only to leveling the playing field between countries, but for the actual long-term digital development in the aspect of the European Single Market.

Moreover - and this should be particularly emphasized - the analysis of conditions in this respect is one of the basic elements necessary in the strategic planning process, including in the development of policies. This applies to every sector of the economy, including those that fulfill critical functions, such as the arms industry, banking, telecommunications or energy [32-34]. Within the energy sector, for example, the transformation of this market is indicated, taking into account its digitization. For entering the market of the so-called smart grids, interconnected and interoperable trading systems, as well as energy management, with appropriate use of the potential of artificial intelligence, will undoubtedly result in a change for both energy suppliers and consumers (also prosumers and their position on the market). Moreover, progress in the digitization of energy has a direct impact on the level of security, efficiency, availability and durability of energy systems. Therefore, it is important to analyze the conditions for the development of the digital economy and society as a basis for detailed analysis related to e.g., the development of digitization in the energy sector. It is impossible to separate the context, in this case, of general determinants from their detailed analysis. This paper is, therefore, a specific introduction to the issue of analyzing the conditions for the development of the digital economy and society of EU countries, which may be a starting point for detailed analysis, e.g., concerning the digitization of the energy sector.

To achieve these goals the paper is organized as follows: Section 2 presents a literature review on the issues of digital economy and society in the context of digital convergence, in Section 3 the authors present a methodological framework for measuring the digital convergence in EU-28 Member States; Section 4 includes the analyses of collected data, using basic measures of dynamics of time series and the cluster analysis. In Section 5 the authors present the discussion of findings and, in Section 6, the conclusions.

\section{The European Union's Digital Economy and Society and Digital Convergence}

Digital economy means the economy of goods and services whose development, production, sale or supply are wholly dependent on digital technologies [35]. It can also be defined as "a combination of several general-purpose technologies (GPT) and many economic and social activities carried out by people via the Internet and related technologies. It includes the physical infrastructure on which digital technologies (broadband lines, routers) are based, the devices used for access (computers, smartphones), the applications that power it (e.g., Google, Salesforce), and the features that provide it (Internet of Things, data analytics, cloud computing)" [36]. In this respect, digitalization is seen as the integration of data and the Internet into production processes, new forms of consumption within households and the public sector, capital formation, cross-border flows and finance. Definitions of the digital economy in the literature of the subject are presented in different 
sources [37-39]. The analysis of the definition of the digital economy clearly indicates its evolutionary nature in a timely context, but it should nevertheless be emphasized that all definitions give some acknowledgment that digital technologies of some kind are the foundation for the digital economy [40-42]. However only a few, in their explanations, identify the production of these technologies and related foundational services as part of-indeed as the core of-the digital economy [43]. One of the current comprehensive definitions is proposed in the following: "The Digital Economy incorporates all economic activity reliant on, or significantly enhanced by the use of digital inputs, including digital technologies, digital infrastructure, digital services and data. It refers to all producers and consumers, including government, that are utilising these digital inputs in their economic activities" [44]. It is worth mentioning here that the global digital economy amounted to an estimated USD 11.5 trillion (16\% of global GDP) in 2015 and is forecast to total over USD 23 trillion (24\% of global GDP) in 2025 [45]. The digital economy is becoming increasingly relevant for growth in the world's countries. The United Nations' Economic Commission for Latin America and the Caribbean (ECLAC) estimates that the digital economy contributed an average 3.2\% to GDP in Argentina, Brazil, Chile and Mexico combined. However, in Japan it is 6.8\%, in the United States of America 6.4\% and in the European Union $5 \%$ [46].

On the other hand, the concept of 'digital society' is closely linked to the digital economy, as the infrastructure created within the economy is the basis for the creation of a digital society. There are many definitions of the concept of digital society in the literature of the subject, which analyze their contemporary usage in different research approaches and discuss their social, political, cultural, ethical and economic relevance and impact $[47,48]$. In a fairly broad sense, the digital society can be described as "a modern, progressive society that is formed as a result of the adoption and integration of Information and Communication Technologies (ICT) at home, work, education and recreation, and supported by advanced telecommunications and wireless connectivity systems and solutions" [49].

As indicated earlier, the development of the digital economy and society is cited as the foundation of growth in the twenty-first century. The information and communication technology (ICT) sector plays a particular role in this regard, the importance of which for the development of the world economy, including the economies of its regions (Europe, America, Asia, etc.), is expressed by dynamic growth. Key trends in the sector include cloud technologies, Big Data, the Internet of Things, and cybersecurity. It is worth mentioning that the revenues of segments covered by key trends are growing at a rate of several to tens of percent per year (and digitally advanced sectors are growing on average 2.8 times faster than other sectors) and are projected to grow further [50], with significant competitive advantages and savings. As already mentioned, the development of the digital economy applies to every area, including the energy sector [51,52]. The current challenges and opportunities related to the digitization of the energy sector and the development of this area of the economy include: [53-55]:

- The transition of electric power supply systems to the Industrial Internet of Things concept (using a network of sensors to monitor energy demand, manage its transmission and storage);

- Using Artificial Intelligence to optimize energy transmission and distribution;

- Management of energy resources and logistics using e.g., blockchain, which in turn increases the potential of operational efficiency in the activities of energy companies;

- Monitoring of changes in demand with the use of smart grids and models of responding to changes in this area, which allows not only monitoring but also an autonomous response to these changes through appropriate energy distribution;

- Creating the so-called Virtual Power Plants, i.e., systems integrating various energy sources for the purposes of distribution management and demand production control;

- Creating energy management systems by consumers and prosumers to optimize energy production and consumption, along with the analysis and offer of optimal 
energy use from various sources. For the purposes of such a system, the so-called smart meters or IoT devices at the consumer (mobile reporting applications). The use of such systems also has an educational value, related to the increase in environmental awareness of users;

- $\quad$ The use of digital modeling to design both new energy networks, as well as to improve the existing ones. The use of this tool will have a direct impact on the operational efficiency of economic entities from the energy sector, as it will allow for faster data analysis (compared to existing solutions) on the basis of real energy networks to prepare new investments, including reducing the costs of designing new installations;

- $\quad$ The use of blockchain, i.e., security and automation of transactions within the energy network, e.g., when selling micro-amounts of energy between prosumers;

- building systems in the form of the so-called "digital twins". A digital replica of a physical object works in real-time with this object, making decisions regarding, for example, optimization of the operation and maintenance of physical fixed assets, production systems and processes in energy, design, organizing information, estimating project profitability, improving update processes, etc.

Emerging development challenges in the global economy, including information and communication technologies, have become an important reference point in the EU policy and EU strategic orientation [56,57]. The European Union's Europe 2020 development strategy [58] focused on three priorities to address the challenges of the coming decade [59-61]:

1. Smart, knowledge-based and innovation-based development;

2. Sustainable development (efficient use of resources, more environmentally friendly while increasing competitiveness);

3. Inclusive development (social, territorial cohesion, with a high level of employment of the population of EU countries).

These priorities relate to the so-called flagship initiatives, which should include the Digital Agenda for Europe. It requires the best use of information and communication technologies to create a sustainable digital future [19]. In this respect, the Agenda identified seven priority areas for action [62]:

- The creation of the Digital Single Market;

- Improving the framework conditions for interoperability between information and communication technology products and services;

- Increase trust in the Internet and the security of its operations;

- Ensuring access to a much faster Internet;

- An increase in research and development expenditure;

- Developing digital literal use and inclusion skills;

- The use of information and communication technologies to address the challenges facing society, such as climate change, rising medical costs and an aging population.

The creation of the Digital Single Market has been identified as the first priority area of action, however, in order to be able to carry out this task, action is needed in the other six areas as they are interlinked. In 2015, the Digital Single Market Strategy was adopted, based on three pillars of [63]:

1. Ensuring easier access for consumers and businesses to digital goods and services across Europe;

2. Creating an appropriate and level playing field enabling digital networks and innovative services to flourish;

3. Maximizing the growth potential of the digital economy.

An important aspect of the changes and policies relating to the Digital Single Market was the presentation by the Commission in 2018 of the "AI strategy for Europe", which assumes activities in the field of technology, ethics, law and economics and in ethics guidelines for trustworthy artificial intelligence (AI) in 2019 [64]. In its Communication of June 2020, "A decisive moment for Europe: repair and preparation for the next generation", the European Commission made it clear that the recovery of the EU economy after the 
end of the COVID-19 pandemic should take place thanks to the Digital Single Market [65]. That is why it is so important that the digital market in the EU is truly a single market, which promotes its global competitiveness and its ability to achieve competitive advantages in the future as well.

Research on this issue relates to the subject of broadly understood convergence, i.e., the theoretical conceptualization of the problem of equalization of the leveling of development of EU countries and, in this regard, the digital economy and society. The term convergence is derived from Latin convergere and means the fact that two or more things, ideas, etc. become similar or come together. The concept of convergence applies both in science and natural sciences, but also in the humanities and social sciences, including economics (e.g., a convergence of countries in terms of per capita income) or management science (strategic convergence of enterprises). In etymological terms, convergence means the likeness of individuals in a certain respect, which occurs economically and technically when the variation in the level of development under examination and in relation to the population studied is reduced or explained as reducing the development distance (catching up) by countries with initially lower/low development rates compared to countries with higher/high levels of development [66].

The authors of the paper adopted the author's definition of the concept of 'digital convergence of EU markets' as a multidimensional phenomenon related to the similarization of EU economies and societies in terms of access, use and digitalization outcomes, including access to and use of modern technologies and forms of social communication, taking into account systemic actions in this field. However, it should be borne in mind that the aim of the digital convergence processes of EU markets is not to achieve a single fully homogeneous market but to create a market in which individual countries can implement their own specific policies in line with the overall dimension of horizontal actions.

From an economic point of reference, at least two-pillar dimensions of the digital convergence of EU markets should be taken into account:

1. The horizontal dimension of economy-wide actions, including the regulation of universal law, solutions and universal capabilities [67];

2. The dimension of specific actions based on analysis, understanding of barriers and development opportunities of countries, but also specific sectors, industries, groups of actors, etc. $[68,69]$.

On the other hand, there are four dimensions (which, however, are differentiated by education, income, occupation, place of residence, as well as the current stage of life of the members of the society concerned) [70,71]:

1. Motivational dimension, related to the mental approach of society to modern technologies and means of communication;

2. The material dimension relating to society's access to these tools, resources, etc;

3. The personal dimension, concerning the ability of members of the public to acquire, maintain and upgrade acquired capacities;

4. The dimension of the use of technology and the social impact achieved.

The development of the digital economy and society is a multifaceted issue, economic, social and technological in nature. Most often, certain components are taken into account in the studies including, in particular:

1. Willingness to develop on the resource and skills side, which are necessary for its occurrence;

2. An increase, expressed in the availability and use of the necessary tools, techniques, methods, functions, etc. on the road to digital development;

3. Impact-economic impact and effects obtained.

Furthermore, an important element of these processes is also the problem of media convergence, including their accessibility (infrastructure), use (including aspects of legislation) and the resulting effects on the economy and society. In this respect, six dominant interpretations of this term are revealed: 
- The convergence of networks;

- The convergence of terminals;

- The convergence of services;

- The convergence of rhetoric;

- The convergence of markets;

- The convergence of regulatory regimes.

The first one implies that, when digitized, any network can be used to transmit all kinds of digital signals, provided that speed and bandwidth are high enough] [72]. Baldwin et al. [73] envisioned the development of a "full service network", a network that would integrate telephony, data and video, providing a broad range of communication services and information. It means one network for communication purposes.

Another interpretation of convergence is the convergence of terminals, which can be analyzed as "the coming together of consumer devices such as the telephone, television and personal computer" [74]. Some authors [75,76] assume even that all terminals could be reduced to one $[28,41]$. However, observing current trends, it can be seen that different types of terminals are becoming less obvious, as many of them can be used for multiple purposes, different terminals are still constructed for and used in different social settings and the number of specialized terminals is still increasing [72]. The third type of interpretation of media convergence in the literature of the subject is the convergence of services. As Beyer et al. rightly point out [77] new services have been developed within and across media platforms. Nevertheless, although the services cross-media platforms, we can observe that the platforms themselves are still relevant.

The term "rhetorical convergence" is used to describe the process where new genres are created by mixing traits known from genres in different earlier media [72]. In Nielsen's words there should be "a rhetorical convergence in which expressions and genres would no longer be distinct, but grow into one unified language" [72].

The aforementioned interpretations of media convergence, i.e., a convergence of networks, terminals and services, was further expected to lead to a convergence of markets. As it is noticed by Picard [78], or Hoskins et al. [79], ICT, telecom and media companies would merge or form alliances, so we would see the development of multimedia companies. However, the market itself is not and most likely will never be fully homogeneous. Fagerjord and Storsul rightly emphasize that in the market web, some corporations seek control of the whole value chain through vertical expansion, whereas others specialize in narrow sub-markets [72].

The perceptions of convergence (presented above) with communication networks, terminals, services and markets have had a strong impact on the political discourse. As indicated by the Østergaard [80] regulations of telecommunications, media and other media services had earlier been closely attached to the networks delivering the service. Therefore, consultations are being undertaken within the EU on the impact of planned legislative changes on convergence processes. This is justified by both horizontal and specific policy considerations (it is worth mentioning that, as early as the late 1990s, some researchers pointed to the inconsistencies between the technological and the regulatory levels [81-83]). Regulations in the EU and in the individual countries have been integrated into common regulatory frameworks for electronic communications, so the networks have one common regulatory framework.

Measuring the convergence process itself, both in relation to the above-referred research perspectives and to the Union market as a single market composed of many, is not an easy task, but nevertheless, the development of appropriate measurement tools is necessary in this respect [84]. They form the basis for carrying out analyses, evaluations and drafting of amendments. However, traditional methods and tools for measuring economic development are often unable to capture the changes taking place in the digital world. Therefore, different methods are developed and different indicators are used to assess and compare the digital development performance of different economies and societies [85-88]. 
For the purpose of measuring progress in the development of the digital economy and society, a Digital Economy and Society Index (DESI) has been developed and adopted in the European Union, taking into account five baseline sub-indicators, i.e., connectivity, human capital, use of the internet, integration of Digital Technologies, and Digital public services. At the level of its respective dimensions, DESI refers to the five main EU policies relevant to the development of the digital economy and society. These areas are interlinked, so the development of the digital economy and society requires the implementation of improvement processes in all these areas at the same time. Connectivity covers the deployment of broadband infrastructure and its quality; human capital relates to skills needed to take advantage of the possibilities offered by a digital society. These are the most relevant dimensions of DESI because they represent the infrastructure of the digital economy and society. Integration of digital technology captures the digitalization of businesses and development of the online sales channels. It mirrors, therefore, the use of ICT by the business sector, which is one of the most important drivers of growth. The last two dimensions are the use of the Internet, reflecting the variety of activities performed by citizens already online, and digital public services, related to the digitalization of public services, focusing on eGovernment. They are enabled by the infrastructure and their contribution to the digital economy and society is strengthened by the quality of such infrastructure [89].

The DESI indicator and its sub-indicators not only provide an opportunity to assess the current state of play but also to compare the achieved position of the economy in relation to others in the EU. Studies in this regard, included in the form of time series, also allow us to determine the dynamics and directions of change, and on the basis of them to formulate assessments of these changes in the development of the economy and digital society of individual EU countries, their groups/clusters or the European Union as a whole [90-95]. Finally, research efforts illustrate whether (or not) progress is being made towards a Digital Single Market as a consequence of the existing digital convergence (divergence) between EU countries in the light of economic development policies and the digital society [96]. There is also the International Digital Economy and Society Index (I-DESI) which enables trend analysis and comparison of the digital performance of 45 countries: the EU27 Member States and 18 non-EU countries around the world (Australia, Brazil, Canada, Chile, China, Iceland, Israel, Japan, Mexico, New Zealand, Norway, Russia, Serbia, South Korea, Switzerland, Turkey, the United Kingdom, and the United States). Comparisons enable the identification of gaps between the performance and capabilities of the 45 countries studied and are useful to identify areas requiring investments and actions to reach the levels of the best performing global countries and to monitor the progress of the 2020 EU digital strategy.

It should be remembered that the adopted digital strategy of the European Union has a direct impact on the functioning and development of national economies, their enterprise sector, and in particular those that use the achievements of the digital economy in their activities, including those relating to the broadly understood industry 4.0. As it is depicted in the literature review, digital economy and society are very broad terms related to the effects of industrial revolutions, which are conditions for the development of business, i.e., economic entities and societies. These are issues that require a holistic view, also in terms of long-term effects.

It cannot be forgotten yet that in respect to technological convergence of the EU countries that has been proved econometrically for the years 1995-2009 (Research based on several dozen econometric models [97]), convergence alone is not enough if the mechanism is mainly imitation rather than innovation. The implementation of progress must be based on a qualitative reference in order to create changes. This means that the digital convergence of EU markets should move towards achieving the best possible position for a country, with continuous improvements, including those with the best results, for pro-innovation activities. 


\section{Materials and Methods}

Data on the evolution of the Digital Economy and Society Index (DESI) and its five subbenchmarks have been used to measure the progress made by European Union countries in the development of the digital economy and society and to assess whether and in what areas the digital convergence process takes place. The analysis was based on data from 2015 to 2020. They covered 28 countries of the European Union. The basic data source was the data available on the European Union website in the Euro-stat database [98]. The DESI has a three-level structure: dimensions, subdimensions, indicators. In our analysis, we focused on the DESI and its five highest level dimensions that make up the overall DESI index. As some dimensions, subdimensions, and indicators are more relevant than others, they were given higher weight in the computation of the final index for each country. Weights attributed to the DESI dimensions are as follows: Connectivity 25\%; Human capital 25\%; Use of internet services 15\%; Integration of digital technology $20 \%$; Digital public services 15\%. Figure 1 presents data concerning the DESI indicator and its components using adequate country indicators whereas Appendix A (Tables A1 and A2) contains initial data regarding DESI and its particulars (before weights).

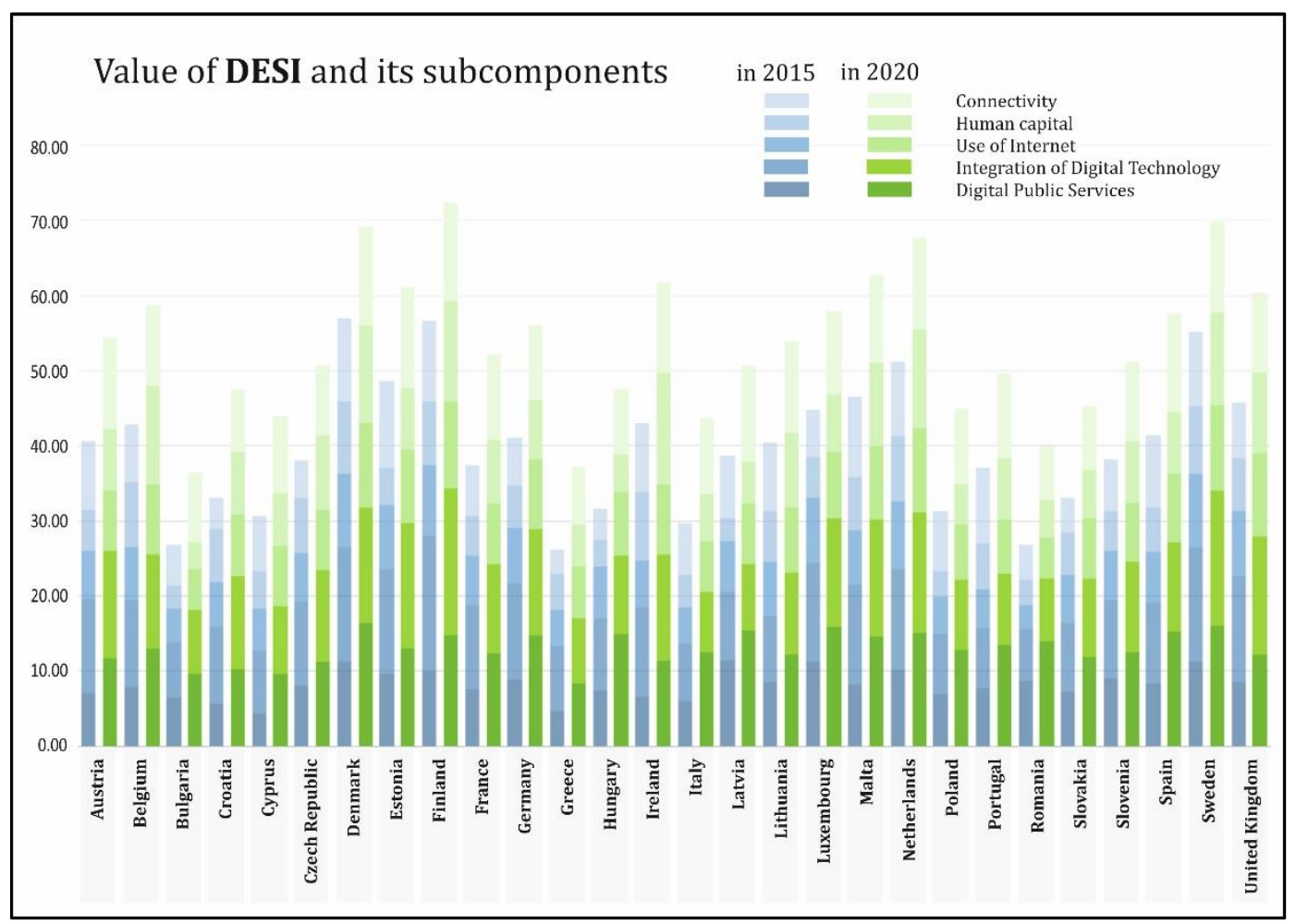

Figure 1. Value of DESI and its subcomponents for EU-28 countries in 2015 and 2020 Source: Our own study based on European Commission data available on the https:/ / digital-agenda-data.eu/ (accessed on 23 October 2020).

The empirical research was carried out in two phases. Firstly, basic measures of time series dynamics, i.e., average absolute increment and average change index, were used to determine the dynamics of changes in index values. On the other hand, in order to classify countries in terms of the similarity of the value and structure of the DESI index, a cluster analysis was used as one of the basic methods of so-called unsupervised grouping [99]. Cluster analysis is a set of methods of multidimensional statistical analysis, used to extract homogeneous subsets of objects of the study population. Finding groups (clusters) of objects is based on variables that characterize the analyzed objects. The method shown uses measures of discrepancy or distance between objects when forming clusters. The most direct way to calculate the distance between objects in a multidimensional space is to calculate the Euclidean distance. However, often in this analysis a different metric can be 
taken as a measure of distance. In addition, it is also possible to estimate the distance of objects without using a metric. This research uses the Ward method. This method uses a variance analysis approach to estimate the distance between the focus. Thus, this method aims to minimize the sum of squared deviations of any two clusters that can be formed at any stage of the algorithm [100]. The chosen method is considered to be the most effective, although it aims to create clusters of a small size [101]. For the data considered, no significant linear relationships between the different variables were found. The selection of the number of clusters is based on the difference between the maximum similarity within the groups and the minimum [102]. On this basis, an optimal number of concentrations of five was established. Cluster analysis was carried out with the use of the Statgraphics 18 program, while the figures were prepared with the use of Excel and Corel Draw.

\section{The Digital Economy and Society in the Countries of the European Union in 2015 and 2020. Convergence or Digital Diversity? Results of Empirical Studies}

The DESI synthetic index illustrates the level of development of the digital economy and society, which today is one of the most important determinants affecting the standard of living of the population, as well as the competitiveness of the economies of individual EU countries and the European Union as a single market in the context of the Digital Single Market strategy. Using the Ward method, based on the DESI data in 2015 and 2020, the EU-28 countries were divided into cluster structures. Among the EU-28 countries, 5 clusters were distinguished in each of the analyzed years. Dendrograms are presented in Figures 2 and 3.

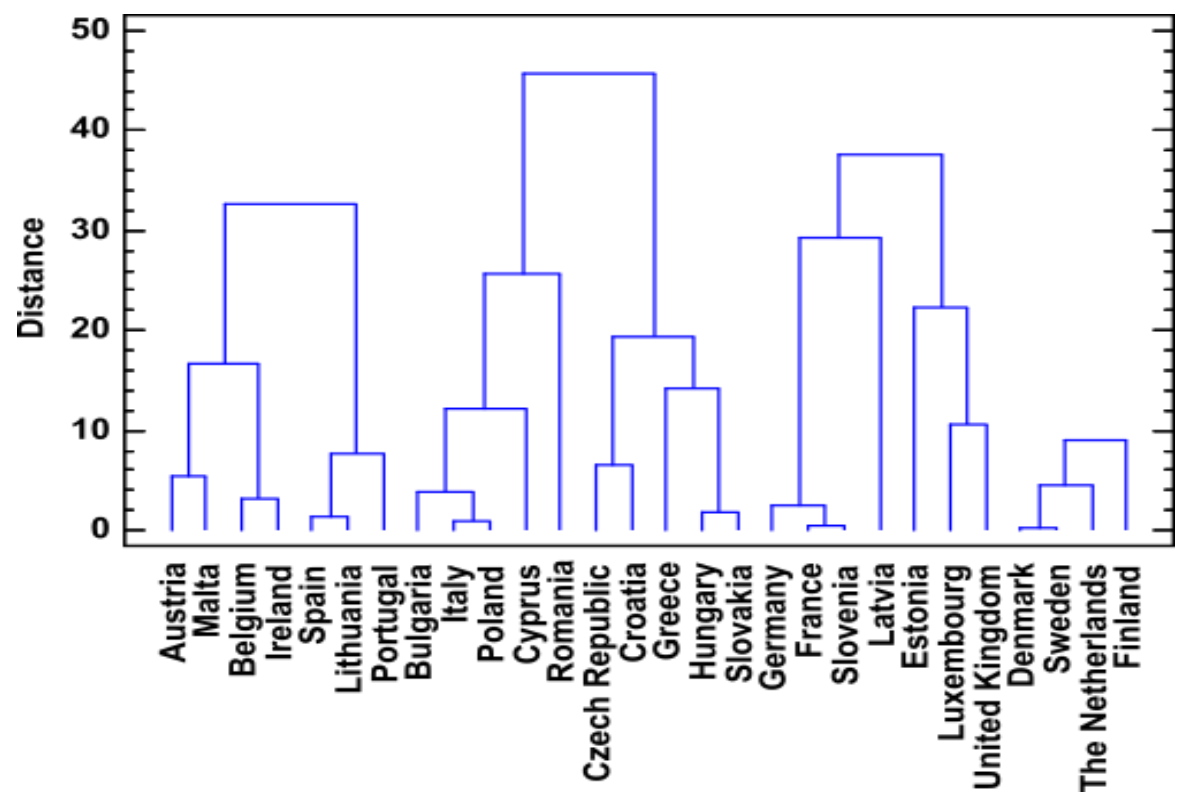

Figure 2. Ward's dendrogram for the EU-28 Member States in 2015. Source: Our own study.

The selection of countries for individual clusters was dictated both by the DESI values obtained and by the values within its internal structures, which consisted of the following components: connectivity, human capital, use of internet services, integration of digital technology, digital public services. It can be seen that Cluster 1 includes those countries whose DESI in 2015 and 2020 was the lowest among the EU-28 countries analyzed. Cluster 5 , on the other hand, includes the countries which achieved the highest values in the years analyzed, both for DESI and for the components separated within it. Detailed data on the average values of indicators for particular clusters are presented in Figure 4. 


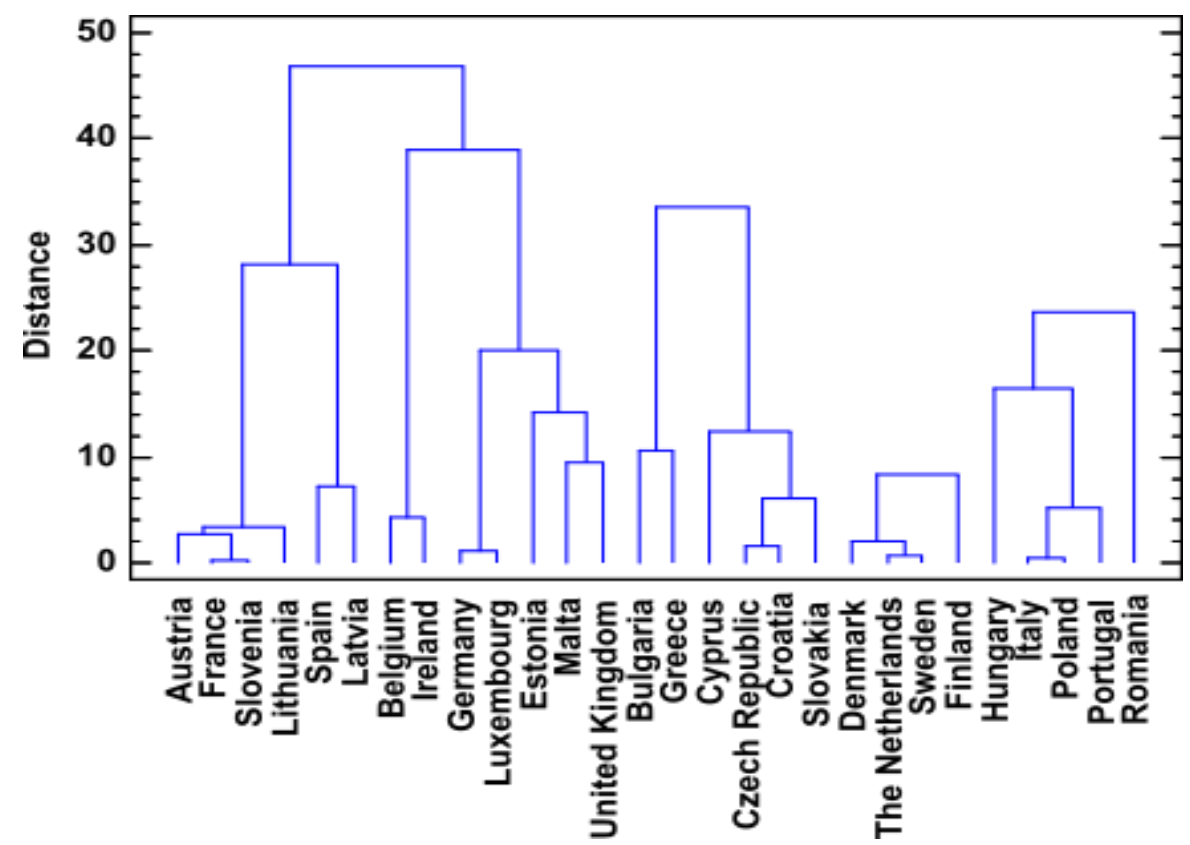

Figure 3. Ward's dendrogram for the EU-28 Member States in 2020. Source: Our own study.

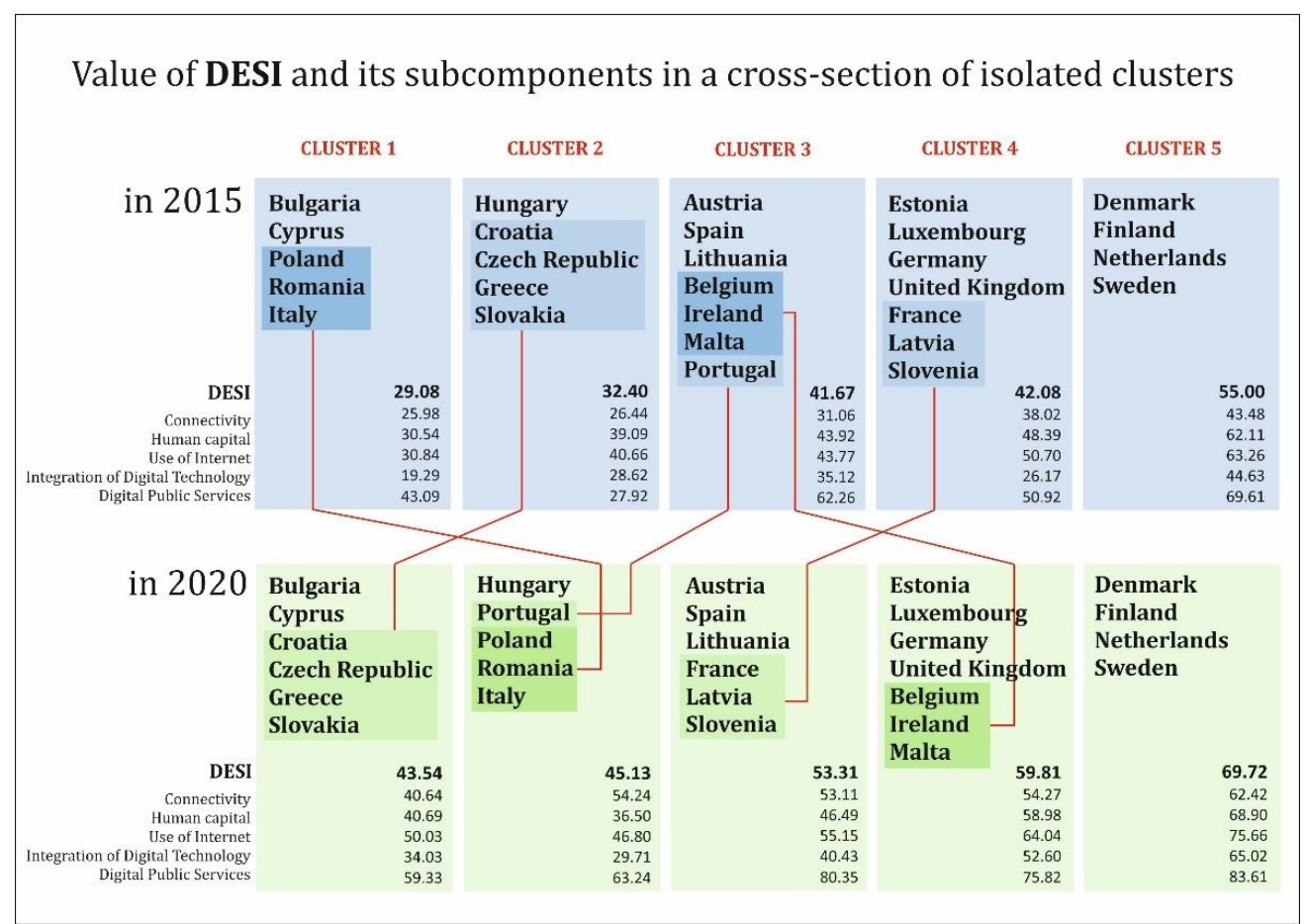

Figure 4. Value of DESI and its subcomponents in a cross-section of isolated clusters. Source: Our own study.

Looking at the data by country, the DESI indicator showed changes compared to the two surveyed years, i.e., 2015 and 2020. The noted change should be assessed positively, as it entails a higher level of digitization of the economy and society during the period considered in the EU, which in turn entails the gradual acquisition of the assumptions made in the Digital Single Market strategy. In the years adopted, the analysis of 14 out of 28 EU countries showed DESI values below average, and the other half above the EU average. Countries with below-average EU values in 2015 and 2020 included Bulgaria, Cyprus, the Czech Republic, Greece, France, Croatia, Hungary, Italy, Latvia, Poland, Portugal, 
Romania, Slovenia, Slovakia. The lowest DESI was recorded in 2015 in Greece (26.13 points) and in Bulgaria in 2020 (36.44 points). In contrast, the following EU countries achieved DESI above the EU average: Austria, Belgium, Germany, Denmark, Estonia, Spain, Finland, Ireland, Lithuania, Luxembourg, Malta, the Netherlands, Sweden and the United Kingdom, with the highest values recorded for Denmark, Finland and Sweden in both years.

When analyzing data on the performance of individual countries in relation to the EU-28 average (Table 1), it can be concluded that:

- In 2015, the lowest rate recorded for Greece was $67.16 \%$ of the EU-28 average and the highest for Denmark was $146.44 \%$;

- In 2020, the lowest rate recorded for Bulgaria was $69.25 \%$ of the EU-28 average and the highest for Finland was 137.42\%.

Table 1. Data summary and evaluation of the obtained values in terms of DESI measures and its sub-indicators for the countries with the lowest and the highest values in relation to the EU average in 2015 and 2020. Source: Our own study.

\begin{tabular}{|c|c|c|c|c|c|c|}
\hline \multirow{2}{*}{\multicolumn{2}{|c|}{$\begin{array}{c}\text { Share in Relation to the EU-28 Average of } \\
\text { the Lowest and the Highest Score of the } \\
\text { Countries } \\
\text { That Year }\end{array}$}} & \multicolumn{2}{|c|}{ Included: } & \multirow{2}{*}{$\begin{array}{c}\text { Difference } \\
\text { [P.P.] }\end{array}$} & \multirow{2}{*}{$\begin{array}{c}\text { Degree of } \\
\text { Recorded } \\
\text { Differences in DESI } \\
\text { Components in the } \\
\text { Analyzed Periods }\end{array}$} & \multirow{2}{*}{$\begin{array}{l}\text { The Assessment of } \\
\text { Changes } \\
\text { in the Context of } \\
\text { Implementing } \\
\text { Convergence Processes } \\
\text { in a Given Area }\end{array}$} \\
\hline & & $\begin{array}{c}\text { Lowest Values } \\
{[\%]}\end{array}$ & $\begin{array}{c}\text { Highest Values } \\
{[\%]}\end{array}$ & & & \\
\hline \multirow{2}{*}{ Connectivity } & 2015 & 56.0 & 146.2 & 90.2 & \multirow{2}{*}{ degree 3} & \multirow{2}{*}{+} \\
\hline & 2020 & 66.7 & 131.5 & 64.8 & & \\
\hline \multirow{2}{*}{ Human Capital } & 2015 & 62.4 & 164.1 & 101.7 & \multirow{2}{*}{ degree 1} & \multirow{2}{*}{+} \\
\hline & 2020 & 65.8 & 159.1 & 93.3 & & \\
\hline \multirow{2}{*}{$\begin{array}{l}\text { Use of Internet } \\
\text { Services }\end{array}$} & 2015 & 48.2 & 145.1 & 96.9 & \multirow{2}{*}{ degree 4} & \multirow{2}{*}{+} \\
\hline & 2020 & 61.9 & 131.6 & 69.7 & & \\
\hline \multirow{2}{*}{$\begin{array}{c}\text { Integration of } \\
\text { Digital Technology }\end{array}$} & 2015 & 52.3 & 164.1 & 111.8 & \multirow{2}{*}{ degree 2} & \multirow{2}{*}{ - } \\
\hline & 2020 & 43.2 & 179.6 & 136.4 & & \\
\hline \multirow{2}{*}{$\begin{array}{l}\text { Digital public } \\
\text { services }\end{array}$} & 2015 & 41.0 & 153.9 & 112.9 & \multirow{2}{*}{ degree 5} & \multirow{2}{*}{+} \\
\hline & 2020 & 67.3 & 124.1 & 56.8 & & \\
\hline \multirow{2}{*}{ DESI } & 2015 & 67.2 & 146.4 & 79.2 & \multirow{2}{*}{-} & \multirow{2}{*}{+} \\
\hline & 2020 & 69.3 & 137.4 & 68.1 & & \\
\hline
\end{tabular}

Clarification: degrees 1-5 mean ordering values of indicated differences between 2020 and 2015, where degree 1 means the lowest and degree 5 means the largest difference; " + " positive rate of indicated changes in the context of implementing indicated changes in convergence processes (enlarging convergence); " $"$ " negative rate of indicated changes in the context of implementing indicated changes in convergence processes (reducing convergence).

The decreasing gap between the lowest and highest rates in relation to the EU average (79.28 pps in 2015 and 68.17 pps in 2020) shows that convergence between EU-28 countries is gradually increasing which, overall, is a positive development. The positive results are also confirmed by the improvement in the relationship between the results of the countries with the highest and lowest rates, which decreased from 2.18 in 2015 to 1.98 in 2020.

Table 2 shows the dynamics of the average DESI values and their individual sub-factors for the period 2015-2020 in the cross-section of the isolated clusters. The results of studies on the development of DESI in individual clusters have led to the following conclusions:

1. For Cluster 1 in 2015, the DESI was 29.08 points and in 2020 it was 43.54 points, an increase of $49.74 \%$. The achieved indicator values for Cluster 1 were below the UNION average;

2. For Cluster 2 in 2015, DESI was 32.40 points and in 202045.13 points, an increase of $39.32 \%$. The DESI values obtained for this cluster were below the Union average;

3. For Cluster 3 in 2015, DESI was 41.67 points, then increased to 53.31 in 2020, i.e., by $27.92 \%$, and its values in both 2015 and 2020 were above the Union average;

4. For Cluster 4 in 2015, DESI accounted for 42.08 points, after which it increased to 59.81 in 2020 , i.e., by $42.13 \%$, and its values in both 2015 and 2020 were above the Union average; 
5. For Cluster 5 in 2015, DESI was 55.00 points, then increased to 69.72 in 2020, i.e., by $26.76 \%$, and its values were both above the EU average in 2015 and 2020.

Table 2. Dynamics of average DESI and individual sub-rates in 2015-2020 (2015 = 100\%).

\begin{tabular}{|c|c|c|c|c|c|c|}
\hline Cluster Number & DESI & Connectivity & Human Capital & $\begin{array}{c}\text { Use of } \\
\text { Internet Services }\end{array}$ & $\begin{array}{c}\text { Integration of } \\
\text { Digital Technology }\end{array}$ & $\begin{array}{c}\text { Digital Public } \\
\text { Services }\end{array}$ \\
\hline 1 & 149.74 & 156.41 & 133.23 & 162.23 & 176.41 & 137.68 \\
\hline 2 & 139.32 & 205.16 & 93.36 & 115.11 & 103.81 & 226.47 \\
\hline 3 & 127.92 & 170.98 & 105.84 & 126.00 & 115.10 & 129.04 \\
\hline 4 & 142.13 & 142.73 & 121.88 & 126.33 & 200.96 & 148.89 \\
\hline 5 & 126.76 & 146.94 & 110.94 & 119.61 & 145.67 & 120.10 \\
\hline Average EU-28 & 135.23 & 160.81 & 112.04 & 128.92 & 141.57 & 143.39 \\
\hline
\end{tabular}

Source: Our own study.

All clusters showed an increase in the mean DESI. Cluster 1 (almost 50\%), Cluster 4 (just over 42\%), Cluster 2 (just over 39\%), and Cluster 3 and Cluster 5 (almost 28\% and 27\% respectively) showed the greatest momentum between 2020 and 2015.

Sub-indicators representing the individual components of the DESI indicator were also analyzed. In the area of the first partial indicator on Connectivity in 2020, a significant change was observed compared to 2015 , as it increased by $60.8 \%$. It should be noted that the average value of this indicator was significantly higher than that of the overall DESI. The highest growth rates were recorded in countries such as Cyprus, Italy and Hungary, while the smallest was recorded in Estonia, Latvia and Slovenia.

In both 2015 and 2020, 12 countries recorded below the EU-28 average, with countries such as Austria, Bulgaria, Cyprus, Greece, France, Croatia, Ireland, Italy and Slovakia in both years. Hungary, Poland and Portugal also scored below the EU average in 2015, while the Czech Republic, Lithuania and the United Kingdom recorded below the EU average in 2020. In 2015, Cyprus (17.44 points), Greece (18.93 points) and Croatia (22.60 points) scored the lowest score in the connectivity area, while in 2020 it was again Greece (33.37 points) and Cyprus (38.46 points), as well as Bulgaria (38.50 points). It should also be noted that in the countries with the lowest connectivity rates among the EU-28 in 2015, their ratio to the EU average improved in 2020, with the exception of Bulgaria, which deteriorated from the average. An unfavorable change in this relationship also occurred in the Czech Republic, which in 2020 was among the top five countries with the lowest rate in this area.

The above-average EU-28 score, both in 2015 and 2020, was recorded by 16 countries, both of which concerned countries such as Belgium, Germany, Denmark, Estonia, Spain, Finland, Luxembourg, Latvia, Malta, the Netherlands, Romania, Sweden and Slovenia. As already mentioned, the Czech Republic, Lithuania and the United Kingdom have deteriorated compared to the EU-28 average, while it has improved in Hungary, Poland and Portugal. Latvia (45.52 points), Denmark (45.11 points) and Luxembourg (45.10 points) scored the highest in the area of connectivity in 2015. In 2020, these were again Denmark (65.82 points) and Luxembourg (63.35 points) as well as Sweden (64.37 points). Analyzing the performance of the top five countries in 2015, it was found that in all these countries in 2020 their ratio to the EU-28 average deteriorated, which means that the growth rate of their indicators in the area of connectivity was lower than the average in the Union. In 2020, Spain was in the top five, which improved in relation to the EU-28 average. It is worth noting that the list of the top 5 best or worst performing countries among EU countries did not change during the period considered with the exception of the Netherlands, which left the top five best-ranked countries in this area, Italy, which left the top five, and the Czech Republic, which were among the worst five.

By generalization of the presented results in relation to the EU-28 average (Table 1), it can be concluded that: 
- In 2015, the country with the lowest rate in Cyprus accounted for $56.0 \%$ of the EU28 average and Latvia's highest-rate country accounted for $146.2 \%$;

- Greece had the lowest score in 2020 (66.7\% of the EU-28 average), while Denmark had the best result (131.5\% of the EU-28 average).

It can be concluded that, relatively, there is a noticeable decreasing polarization in the area of connectivity (the difference between the lowest and highest rates in relation to the EU-28 average decreased from 90.2 pps in 2015 to 64.8 percentage points in 2020). This means that the countries' performance is getting closer to the EU-28 average, which is conducive to their convergence. This is also confirmed by the change in the relationship between the performance of the countries with the highest and lowest rates, which decreased from 2.6 in 2015 to less than 2 times in 2020. However, it is still quite high.

Looking at the 2015 and 2020 data for each cluster, it was found that:

- In 2015, the average indicator for Cluster 1 and Cluster 2 was below the EU-28 average, Cluster 3 was very close to Cluster 3 , while Clusters 4 and 5 were above the EU-28 average;

- In 2015, almost all countries in Cluster 1 and Cluster 2 (with the exception of Romania in Cluster 1 and the Czech Republic in Cluster 2) had a connectivity ratio below the EU-28 average. In the third cluster, they were three out of four countries (Austria, Ireland, Portugal) and in the Cluster 4 there was one country (France);

- In 2020, the average connectivity value for the first cluster was below the EU-28 average, while in the remaining clusters it was higher than the EU-28 average;

- In 2020, in Cluster 1, all countries did not reach the EU average, Cluster 2 below average had one country (Italy), in Cluster 3-three countries (Austria, France and Lithuania) and in Cluster 4 there were another two (Ireland and the United Kingdom).

In all clusters, the average connectivity indicator increased in the period 2015-2020, with Cluster 2 (an increase of just over 105\%), followed by Cluster 3 (an increase of nearly $71.0 \%$ ) Cluster 1 (just over $56.0 \%$ ) and the smallest for Cluster 5 (close to $47.0 \%$ ) Cluster 4 (close to $43.0 \%$ ).

In the second area of the DESI-Human Capital, the sub-indices of each country also increased. In 2015, the average score at EU-28 level was only 12.0\% higher. In all countries except Latvia, there has been an improvement in internet literacy and basic and advanced digital skills held by Citizens of the European Union in the years analyzed, as measured by indicators that make up the human capital index. The highest percentage increase was recorded in countries such as Lithuania, Romania and Croatia, while Denmark, Greece, Italy and Latvia were the least dynamic, with the index deteriorating as mentioned.

In 2015, 14 countries scored below the EU average, while in 2020 as many as 16 countries scored below. In 2015 these were Bulgaria, Cyprus, Greece, Spain, Croatia, Hungary, Italy, Lithuania, Latvia, Poland, Portugal, Romania, Slovenia and Slovakia, and in 2020 they were joined by the Czech Republic and France. In both 2015 and 2020, the lowest human capital ratios were in Romania (27.47 points and 33.16 points), Bulgaria (29.18 points and 33.92 points) and Italy (30.81 points and 32.46 points). The above-average EU-28 score in both 2015 and 2020 was recorded in 12 countries: Austria, Belgium, Germany, Denmark, Estonia, Finland, Ireland, Luxembourg, Malta, the Netherlands, Sweden and the United Kingdom, and in 2015 the Czech Republic and France. In 2015, Finland (72.21 points), Sweden (61.26 points) and Denmark (60.63 points) achieved the highest human capital score. In 2020, these were again Finland (78.44 points) and Sweden (71.72 points) as well as Estonia (66.66 points). It is worth noting that the list of the top 5 countries has not changed significantly with the exception of Denmark, which was replaced by the Netherlands. In turn, Poland and Portugal left the five most vulnerable countries in this area, replaced by Greece and Latvia.

In relation to the EU-28 average (Table 1), it was concluded that:

- In 2015, the country with the lowest rate in this area, Romania, accounted for $62.4 \%$ of the EU-28 average, while Finland's highest-rate country accounted for 164.1\%; 
- Italy had the lowest score in 2020 (65.8\% of the EU-28 average), while Finland had the best result (159.1\% of the EU-28 average), of which it can be concluded that only a slight reduction in polarization in the area of human capital is noticeable in relative (percentage) terms, as the range between the lowest and highest rates in relation to the EU-28 average decreased from 101.7 percentage points in 2015 to 93.3 percentage points in 2020. The ratio of the performance of the countries in the extreme places in the ranking of this indicator has also changed only slightly. In 2015, the ratio of the best performance in the area of human capital of Finland to the lowest rate in Romania was 2.6, while in 2020 the ratio for the highest in the area of human capital of Finland and Italy was 2.4 .

The analyses carried out in terms of isolated clusters also made it possible to draw the following conclusions:

- In 2015, the average indicator for the Human Capital component of Cluster 1 and 2 countries was below the EU average, Cluster 3 was almost at the EU average, while Clusters 4 and 5 were above the EU average;

- Almost all the countries included in Clusters 1 and 2 (with the exception of the Czech Republic in Cluster 2) had a sub-indicator value in this area below the EU average. In the third Cluster, this included three of the seven countries (Spain, Lithuania, Portugal) and in Cluster four there were two countries (Latvia and Slovenia);

- In 2020, the average value of Human Capital in Clusters 1, 2 and 3 was below the EU average, with lower values than the EU average for all countries in these Clusters except Austria in Cluster 3;

- In 2020, in Clusters 4 and 5, the average value of the indicator in the cluster, as well as the values of indicators for all countries in these clusters, were higher than the EU-28 average.

Noteworthy is the fact that in the period 2015-2020 only four clusters increased the average human capital ratio. These were Cluster 1 (an increase of just over 33\% in the cluster), Cluster 4 (an increase of almost 22\%), Cluster 5 (an increase of almost 11\%) and Cluster 3 (an increase of less than 6\%). On the other hand, the average human capital ratio for Cluster 2 countries decreased by just over $6 \%$.

Under Use of Internet services, the average sub-index increased by $28.9 \%$ between 2015 and 2020, with an average increase of 35.2\% overall, significantly less. The highest percentage increase was recorded in countries such as Romania, Ireland and Poland, while Luxembourg, Denmark and Estonia were the least dynamic. Of the 28 EU countries, 15 countries scored below the EU average in 2015. These were the following countries in order, starting with the lowest rate: Romania (21.71 points), Bulgaria, Italy, Greece, Poland (33.42 points), Portugal, Cyprus, Croatia, Ireland, Austria, Czech Republic, Slovakia, Slovenia, France, Spain (44.77 points). Among these countries, the level of the indicator varied significantly as Spain's index was 2.06 times higher than Romania's. This group included Poland, with a relatively poor result, as well as France, a more socio-economically developed country, yet with a rather high agricultural position.

Among the 13 countries with an indicator above the EU average, Latvia (45.04 points), Hungary, Belgium, Malta, Lithuania, Germany, Estonia, Luxembourg, the United Kingdom, the Netherlands, Finland, Sweden, Denmark (65.31 points) were the order. The differences between countries were much smaller than for countries with indicators below the EU average, as the spread between Denmark and Latvia was $45 \%$ points out and this group included 4 eastern European countries (the Baltic States and Hungary). In 2020, the following 16 countries scored below the EU average: Romania (35.89 points), Bulgaria, Italy, Greece, Portugal, Poland (49.64 points), Slovenia, France, Slovakia, Latvia, Austria, Czech Republic, Cyprus, Croatia, Hungary, Lithuania (57.32 points). It appears that Romania, Bulgaria, Italy, Greece, Portugal and Poland remained the weakest countries in this respect. Lithuania and Latvia, which were previously listed above, also joined this group. The spread between Romania and Lithuania was 59.7\%, significantly less than the five years earlier in this group. 
Among the countries with indicators above the EU average, only 12 countries were included in 2020: Luxembourg (58.85 points), Spain, Belgium, Germany, Ireland, Estonia, Malta, the United Kingdom, Denmark, the Netherlands, Sweden, Finland (76.34 points). Lithuania, Latvia and Hungary, therefore, fell out from this group and Spain and Ireland were promoted. The spread between Luxembourg and Finland was 29.7\%, significantly less than in 2015.

In addition, analyzing data in Table 1 , it can be stated that in 2015 , the country with the lowest rate in this area, Romania, accounted for $48.2 \%$ of the EU-28 average, while the country with the highest rate was Denmark at $145.1 \%$. Romania $(61.9 \%$ of the EU28 average) also recorded the lowest score in 2020, while the best one was in Finland (131.6\% of the EU-28 average). Relatively, therefore, there is a clear decreasing polarization in the area of internet service use, and the gap between the lowest and highest rates in relation to the EU-28 average has decreased from 96.87 pps in 2015 to 69.71 pps in 2020). It can, therefore, be concluded that the diversity in the use of online services is decreasing between the EU Member States. This is also confirmed by the spread between the countries with the highest and lowest rates in 2015 and 2020, as the ratio of these results has decreased from 3 times to 2 times. However, it is still substantially high.

The analyses carried out within this component in terms of isolated clusters have concluded that:

- In 2015, the average rate for the Use of Internet component of Cluster 1, 2 and 3 countries was below the EU average, while Clusters 4 and 5 were above that average;

- Almost all the countries included in Cluster 1 and Cluster 2 (with the exception of Hungary in Cluster 2 and Belgium, Lithuania and Malta in Cluster 3) had a subindicator value in this area below the EU average. In Cluster 4, they were two of the seven countries (France, Slovenia);

- In 2020, the average use of Internet value in Clusters 1, 2 and 3 was below the EU average, with lower values than the EU average for all countries in these clusters except Spain in Cluster 3;

- In 2020, in Clusters 4 and 5, the average value of the indicator in the cluster, as well as the values of indicators for all countries in these clusters, were higher than the EU-28 average.

In all clusters, the average Internet usage rate increased in the period 2015-2020, with Cluster 1 (an increase of just over 62\%), followed by Cluster 4 and 3 (an increase of about 26\%) Cluster 5 (by almost 20\%) and the smallest for Cluster 2 (just over $15.0 \%$ ).

In the area of Integration of Digital Technologies, the average sub-index increased by $41.6 \%$, which is more than the Internet service usage rate and the total DESI index. The highest percentage increase was recorded in countries such as Latvia, Estonia and France, while Croatia, Greece and Slovakia were the least dynamic. Of the EU Member States, 15 countries scored below the EU average in 2015. These were the following countries according to the increasing size of the indicator: Bulgaria (15.28 points), Latvia, Romania, Poland (17.27 points), Hungary, Italy, Greece, Estonia, Cyprus, France, Slovenia, Luxembourg, Slovakia, Austria, Germany (28.48 points). The spread between Bulgaria and Germany was $86.4 \%$, which was significantly lower than for countries below the EU-28 average for internet service use (2 times difference). Poland was also in the weak fourth place in this group (in fifth place in Internet services). It is surprising that Germany, which has such a high level of economic development, is included in this group of countries (although it is in the best position).

Among the 13 countries with indicators above the EU average, the order was Spain (29.27 points), Portugal, Lithuania, the United Kingdom, Malta, Croatia, the Czech Republic, Finland, Belgium, the Netherlands, Sweden, Ireland, Denmark (47.96 points). The range between the indicators for Denmark and Spain was 63.9\%. It is worth highlighting the relatively high positions of Lithuania and the Czech Republic, countries neighboring Poland.

By contrast, in 2020, the following 16 countries scored below the EU average: Bulgaria (17.86 points), Romania, Hungary, Poland (26.24 points), Greece, Latvia, Italy, Slovakia, Cyprus, Luxembourg, Germany, Austria, Portugal, Slovenia, Estonia, Spain (41.22 points). The spread 
between Spain and Bulgaria had more than doubled (230.8\%). This group mainly included the same countries as in 2015, but in a slightly different order. A notable exception is France leaving the group and the inclusion of Spain, which in 2015 was above the EU-28 average.

Among the 12 countries with indicators above the EU average, Croatia (41.47 points), France, Lithuania, the Czech Republic, the United Kingdom, Malta, Sweden, Denmark, the Netherlands, Belgium, Finland and Ireland (74.32 points) were among the 12 countries with indicators above the EU average. The spread between Ireland and Croatia was 79.2\% and between Ireland and the United Kingdom (in the middle of the group) only $37.1 \%$. It is worth highlighting the relatively high places of Lithuania and the Czech Republic and, above all, Ireland. Unlike the area of online services, however, the differences between EU countries have widened in terms of the use of digital technologies. As the data in Table 1 indicate, in 2015, the country with the lowest rate in this area, Bulgaria, accounted for $52.3 \%$ of the EU-28 average and Denmark's top $164.1 \%$. Bulgaria ( $43.2 \%$ of the EU28 average) also recorded the lowest score in 2020, with the best in Ireland $(179.6 \%$ of the EU-28 average). Relatively, therefore, there is a clear increase in polarization in the area of digital use, and the gap between the lowest and highest rates in relation to the EU-28 average has increased from 111.8 pps in 2015 to 136.4 pps in 2020). In addition, in 2015 there was more than 3 times the difference between Bulgaria, the country with the lowest rate, and Denmark leading in this ranking, while in 2020 the difference between Bulgaria and Ireland was more than 4 times.

The analyses carried out within the Integration of Digital Technology component in terms of isolated clusters concluded that:

- In 2015, the average value of this indicator for Cluster countries 1, 2 and 4 was below the EU average, while for Clusters 3 and 5 it was above that average. It is, therefore, worth noting that the countries of the fourth cluster were characterized by relatively poor performance in this area compared to the EU average;

- Almost all countries in Cluster 1 and Cluster 2 (with the exception of Croatia and the Czech Republic in Cluster 2) had sub-index value in this area below the EU average. In the third cluster, it was only Austria, and in the fourth cluster as many as six out of seven countries (the exception was the United Kingdom);

- In 2020, the average value of indicators for this component in Clusters 1, 2 and 3 was below the EU average, with lower values than the EU average for all countries in these clusters except Croatia and the Czech Republic in Cluster 1 and France and Lithuania in Cluster 3;

- In 2020, in Clusters 4 and 5, the average value of the indicator in the cluster, as well as the values of indicators for countries in these clusters, were higher than the EU28 average, with the exception of Estonia, Luxembourg and Germany in Cluster 4.

In all Clusters, the average rate in this area increased over the period 2015-2020, with Cluster 4 (an increase of almost 101\%) and Cluster 1 (more than $76 \%$ ) and 5 (almost $46 \%$ ) and Cluster 3 (an increase of $15 \%$ ), and the smallest for Cluster 2 (less than $4 \%$ ).

In the last area analyzed (Digital Public Services) a significant change in data is visible for the two years covered by the survey. The average value of this indicator for the EU-28 increased by $43.4 \%$. In this respect, the change noted must be assessed positively, as it demonstrates progress in the key element of the digital economy, which is digital public services, and at the same time a condition necessary for strictly administrative applications, such as:

- E-government users;

- Partially completed forms;

- Comprehensive online services, including business services;

- The advancement of open data as a condition for greater participation of citizens in such services, as well as the basis for the development of new ICT solutions;

- $\quad$ E-Health. 
An analysis of the country-specific changes recorded revealed that 14 out of $28 \mathrm{EU}$ countries achieved a below-average result in 2015 and 2020. In both years this was the case in Bulgaria, Cyprus, the Czech Republic, Germany, Greece, Croatia, Hungary, Italy, Romania, Slovenia, Slovakia and the United Kingdom and, in addition, in 2015, France and Luxembourg, and, in 2020, Poland and Belgium. The lowest score in 2015 was recorded in Greece (20.62 points), Croatia (27.14 points) and Hungary (28.21 points), while in 2020 in Romania (48.41 points), Greece (51.50 points) and Slovakia (55.61 points).

The second half of EU countries achieved above-average results in the years analyzed. These were Austria, Denmark, Estonia, Spain, Finland, Ireland, Lithuania, Latvia, Malta, the Netherlands, Portugal, Sweden and, moreover, in 2015, Poland and Belgium, and, in 2020, France and Luxembourg. Estonia (77.29 points), Denmark (74.38 points) and Finland (72.12 points) scored the highest score in 2015, while Estonia (89.33 points) and Denmark (87.13 points) and Spain (87.28) scored the highest score in 2020.

In relation to the EU-28 average (Table 1), it was found that:

- In 2015, the lowest rate recorded for Greece was $41.07 \%$ of the EU-28 average and the highest for Estonia was 153.93\%;

- In 2020, the lowest rate recorded for Romania was $67.23 \%$ of the EU-28 average and the highest for Estonia was $124.08 \%$. This clearly attests to the decreasing spread of performance between EU countries in relation to the average (from 112.86 pps in 2015 to 56.84 pps in 2020), which promotes their convergence. The positive convergence process is also confirmed by the improvement in the relationship between the performance of the countries with the highest and lowest rates, as it has decreased from 3.74 in 2015 to 1.85 in 2020 . However, it is still substantially high.

The results of research in the area of Digital Public Services (DPS) in the cross-section of isolated clusters have led to the following conclusions:

1. For Cluster 1 in 2015, the rate was 43.09 points, 59.33 in 2020, an increase of 37.7\%. However, the achieved indicator values for Cluster 1 were below the UNION average;

2. For Cluster 2 in 2015, the DPS was 27.92 points and in 2020 it was 63.24 points, an increase of $126.5 \%$. Despite such significant pro-growth developments, the DPS achieved for this cluster was below the Union average;

3. For Cluster 3 in 2015, the DPS was 62.26 points, then increased to 80.35 in 2020, i.e., by $29.0 \%$, and its values in both 2015 and 2020 were above the Union average;

4. For Cluster 4 in 2015, the DPS accounted for 50.92 points, after which it increased to 75.82 in 2020, i.e., by $48.9 \%$, and its values in both 2015 and 2020 were above the Union average;

5. For Cluster 5 in 2015, the DPS was 69.61 points, then increased to 83.61 in 2020, i.e., by $20.1 \%$, and its values were both above the EU average in 2015 and 2020.

All clusters showed an increase in DPS. The most dynamic changes in the years 2020 and 2015 were compared for Cluster 2 countries, followed by Cluster 4 and Cluster 1, and the smallest for Cluster 3 and Cluster 5.

Summarizing the above considerations and the effects of the empirical research undertaken, it should be emphasized that, in the years 2015-2020, there were similarities between individual EU countries in terms of the results achieved by them in the development of the digital economy and society. The applied statistical methods in the field of structure taxonomy allowed for the identification of a total of five cluster structures, among which the lowest results in the development of the digital economy and society were achieved by countries belonging to Cluster 1, and the highest to Cluster 5 . On the basis of the conducted research, it has been shown that there is a visible increase in convergence between the EU-28 countries with regard to the digital economy and society, based on the main DESI index and its four sub-indicators. For the Integration of Digital Technology sub-indicator, an increasing polarization of results was demonstrated, which should be assessed as a negative phenomenon. The authors of the paper would like to note the emerging need for further research on this subject, with particular emphasis on Integration of Digital 
Technology in order to demonstrate the causes of this state and to formulate possible proposals for changes for specific policies in the EU.

\section{Discussion of Findings}

Our results lead to an identification of 5 groups of the EU-28 countries according to their levels of development of the digital economy and society. Thus, they prove the research results observed in earlier studies indicating the fact of huge differentiation among the EU countries within this issue $[23,68,84]$. On the basis of the data from 2015 and 2020, five cluster groups of countries were isolated basing on similar DESI values and the similarity of values within its five internal structures. The analysis of the clusters shows that their composition in 2020 compared to 2015 has changed significantly. Out of $28 \mathrm{EU}$ countries, 14 have remained in their clusters:

- Cluster 1: Bulgaria, Cyprus;

- Cluster 2: Hungary;

- Cluster 3: Austria, Spain, Lithuania;

- Cluster 4: Germany, Estonia, Luxembourg, the United Kingdom;

- Cluster 5: Denmark, Finland, the Netherlands and Sweden;

At the same time, other countries were promoted:

- from Cluster 1 to Cluster 2: Italy, Poland, Romania;

- from Cluster 3 to Cluster 4: Belgium, Ireland, Malta;

and others have moved to the lower cluster:

- $\quad$ from Cluster 4 to Cluster 3: France, Latvia, Slovenia;

- $\quad$ from Cluster 3 to Cluster 2: Portugal;

- $\quad$ from Cluster 2 to Cluster 1: The Czech Republic, Greece, Croatia, Slovakia.

We have found out that, in fact, the differences in the level of development of the digital economy and society within the EU still exist, despite all the investments and policies made in recent years. Moreover, the countries identified as the least digitally developed in earlier studies remain basically the same, whereas the same refers to the most digitally developed countries [103]. In our research, Bulgaria, Cyprus, Greece, Italy, Poland and Romania in both years are among the two lowest clusters, while Denmark, Finland, the Netherlands and Sweden are the digital leaders belonging to Cluster 5, which groups the most advanced countries in this area. This situation is not surprising, considering that North European Countries are pioneers in promoting digital development [104]. Our analyses show that, in a synthetic assessment, all EU countries showed progress in the digital economy and society, and the transition to a lower cluster concerned those countries that still showed an increase in DESI and individual sub-rates in 2020 compared to 2015. On a cluster basis, DESI and its five subcomponents reported positive dynamics of average sub-index values for clusters, with the exception of Cluster 2, for which the average human capital ratio decreased in 2020 compared to 2015. The results of our research, therefore, confirm that the development of the digital economy and society of the Countries of the European Union is not homogeneous and specific groups of countries (clusters) are distinguished, taking into account the similarity of their performance in this area. The results obtained in this respect, therefore, allow for positive verification of the hypothesis HS1.

Studies have shown that all EU countries have seen an increase in DESI during the analysis period, which should clearly be assessed positively, but the scale of the increases and their dynamics varied significantly. In relative terms, the greatest progress (i.e., the greatest dynamics of change) in 2020 compared to 2015 was shown among countries making up for the development gap in relation to the EU average, such as Hungary, Romania, Italy, while the lowest dynamics were in Denmark, Estonia and Sweden. Our research has also shown that in the five subcomponents that make up the overall DESI index, the performance of individual countries has improved, with different dynamics of change taking place in different areas. The only exception here is Latvia, whose human capital ratio has deteriorated. 
In the area of connectivity, taking into account the average value of the indicator for the EU-28 countries, the most dynamic developments have been recorded, which should be assessed highly positively, as this shows a dynamic improvement in the connectivity situation, both from the demand side and the supply of fixed and mobile broadband. In the area of human capital, it was found that all EU countries except Latvia had seen an improvement in the index, but the dynamics of change here were significantly lower than for the other indicators as well as the synthetic DESI. The changes taking place in this area are, therefore, much slower, as they concern changes in the knowledge and skills of nationals and are the result of existing ICT education solutions in those countries. They are, therefore, evolutionary rather than revolutionary that was also observed in research of others, [105]. The third indicator, for the Use of Internet services area, was relatively high in the years analyzed compared to the other components, and its average value for the EU-28 was second only to those in the area of Digital Public services. However, the growth rate of the EU-28 average was lower than the DESI synthetic index and connectivity, integration of digital technology and digital public services indicators. On the other hand, the dynamics of the average component 4 indicator (Integration of Digital Technology) have only given way to the dynamics of change in connectivity and Digital Public services over the years, which demonstrates the dynamic development of digital technologies and e-commerce channels in the business sector in the European Union. The fifth area examined, Digital Public services, was the second-highest growth rate for the EU-28, indicating the rapidly growing potential of ICT in the public sector, both in demand and in the supply of digital public services and in open data.

Finally, when analyzing the DESI synthetic index and its components, it was concluded that there is generally an increase in the convergence between the EU-28 countries in relation to the economy and the digital society over the years analyzed, however in some dimensions there is evidence that the European digital divide is narrowing, while in the other it appears to be widening. This is evidenced by the positive changes in the relationship between the performance of the countries with the highest and lowest rates: synthetic and in the areas of Connectivity, Human Capital, Use of Internet and Digital Public Services, both in relation to each other and in relation to the EU-28 average. The largest reductions in the range of results for countries with extreme indicator values in 2015 and 2020 were recorded in the areas of Digital Public Services, Use of the Internet and Connectivity. It can, therefore, be concluded that these are the areas where the least developed countries in a given respect make the most progress compared to the leaders' countries and the EU-28 average. Dynamic positive changes in the indicated areas are also confirmed by studies by other authors $[68,106]$. Only a slight increase in the convergence between the EU-28 countries has been recorded in terms of Human Capital, which only confirms the fact that changes are taking place here relatively more slowly than in other areas. Noteworthy is the fact that the area of Integration of Digital Technology was the only one where there was an increasing polarization of results. Unlike other components, in terms of the use of digital technologies, the differences between EU countries widened over the period analyzed; the gap between the lowest and highest performing countries in relation to the EU-28 average increased, and the advantage of the country with the highest score in relation to the worst-performing country also increased. Our findings in this respect are, therefore, in line with those of other authors, indicating that the transition to a digital economy and European society is gradual in all sectors, and its rhythm is dictated by the individual initiatives of the Member States and the corresponding historical economic sectors. European and national initiatives involving both private and public investment in the deployment of new digital technologies provide diverse opportunities for the industry in particular countries to achieve new benchmarks [107].

The results presented clearly confirm that the levels of indicators and the dynamics of changes in their values in 2015 and 2020 in the five baseline areas of the DESI analysis vary despite the fact that almost all of them are pro-growth, including for isolated clusters of EU-28 countries, and the pace of their changes is not uniform, which allows positive 
verification of the hypotheses HS2 and the main hypothesis. However, the direction and dynamics of the changes in indicators across countries indicate different convergence processes in the synthetically understood area of the digital economy and society, as well as in terms of connectivity, human capital, internet use and digital public services. Only in the area of the use of digital technologies have the differences between EU countries widened during the analysis period. The analyses presented are an indication of the European Union administration's efforts to promote the sustainable development of the digital economy and society. They should serve as an indication of the increase in national expenditure on the development of individual components, especially those with a weaker performance of the particular country in comparison with other EU countries.

\section{Conclusions}

The results of the analysis of digitization processes and their effects in the field of Connectivity, Human Capital, Use of Internet, Integration of Digital Technology and Digital Public Services are important for shaping the proper domestic policy of governments, for strengthening the competitiveness of a given country in various areas of the economy and for everyday life. In 2014 the European Commission introduced the Digital Economy and Society Index (DESI). It is a comprehensive measure for the synthesis of data received from individual member countries. The indicator is an effective tool for assessing the economic and social impact of digitization in the EU. Moreover, in recent years DESI has served as an important factor in shaping European policy on harmonious digital development. It is also a reference point for the comparative analyzes of various aspects of digitization in individual EU countries.

In this study, DESI was used for the complete and up-to-date analysis of the economic and social aspects of digitization in the $28 \mathrm{EU}$ countries. It was done in the context of the trend of digital convergence. The results of the analyzes performed can help in shaping the economic policy in Europe. They show the strengths and weaknesses of the digital development strategy in individual EU countries. They also point to those areas where the difference in the dynamics of digitization between more and less digitally advanced countries still remains very noticeable.

The research presented here also has some limitations. Although DESI is a widely used and effective measure of digitization processes, this indicator should be used with some caveats. Its introduction was aimed at providing a unified and standardized image of the comprehensive digital ecosystem that forming inside the EU. The methodology applied here was subject to the requirement of universality, which was aimed to make it effective in research conducted in an individual EU country. For this reason, the obtained results are general in nature and require deeper analysis. This implies the need to collect additional, including qualitative, data to explain certain state-specific phenomena. Another issue that should be noted here is the difference between individual statistical offices and between the methods of collecting data in individual EU countries.

Despite the limitations outlined above, DESI can be regarded as an effective tool for drawing up a comprehensive picture of the complex dynamics of digitization processes in today's Europe. Digital convergence still remains an open problem, which implies the need to deepen the research presented in this paper. Although the analysis of individual clusters presented in the paper may be useful for the quantitative assessment of differences in the dynamics of digitization processes in individual countries, our study does not explain the reason for the existence of such differences. The presented analysis focuses on five main dimensions that make up DESI: Connectivity, Human Capital, Use of Internet, Integration of Digital Technology and Digital Public Services. A more detailed picture of the dynamics of digital development in future research can be obtained by referring to aspects of the process that are more specific than those mentioned above, using second-level data for each dimension. This would allow, inter alia, to explain the existence of significant differences in the dynamics of digitization between individual EU countries. 
Author Contributions: Conceptualization, R.B., J.M., M.S., A.T., K.Ż. Formal analysis, B.S.-T., A.T., K.Ż. Investigation, B.S.-T., A.T., K.Ż. Methodology, M.S.; Resources, K.Ż.; Writing—original draft, B.S.-T., A.T., K.Ż. Writing-review \& editing, R.B., J.M. All authors have read and agreed to the published version of the manuscript.

Funding: The publication is financed by the subsidy granted to the Cracow University of Economics and WSB University in Dabrowa Górnicza. This publication is a component of scientific research carried out at the University of Economics in Cracow as a part of the research of the Potential Program, WSB University in Dabrowa Górnicza as a part of the research carried out at this University and the Faculty of Management of AGH University for the maintenance and development of research potential.

Institutional Review Board Statement: Not applicable.

Informed Consent Statement: Not applicable.

Data Availability Statement: Publicly available datasets were analyzed in this study. This data can be found here: https:/ / digital-agenda-data.eu/ (accessed on 23 October 2020).

Conflicts of Interest: The authors declare no conflict of interest.

\section{Appendix A}

Table A1. Value of DESI and its subcomponents in 2015 in a cross-section of EU-28 countries *.

\begin{tabular}{|c|c|c|c|c|c|c|}
\hline Country & DESI & Connectivity & Human Capital & $\begin{array}{l}\text { Use of Internet } \\
\text { Services }\end{array}$ & $\begin{array}{c}\text { Integration of Digital } \\
\text { Technology }\end{array}$ & Digital Public Services \\
\hline Austria & 40,54 & 28,26 & 50,19 & 42,20 & 28,02 & 59,93 \\
\hline Belgium & 42,82 & 31,44 & 46,38 & 47,19 & 42,84 & 51,46 \\
\hline Bulgaria & 26,81 & 26,10 & 29,18 & 29,51 & 15,28 & 36,73 \\
\hline Croatia & 33,00 & 22,60 & 41,00 & 39,20 & 35,74 & 27,14 \\
\hline Cyprus & 30,65 & 17,44 & 33,55 & 37,48 & 25,00 & 48,52 \\
\hline Czech Republic & 38,10 & 32,38 & 44,86 & 42,60 & 37,20 & 33,04 \\
\hline Denmark & 56,98 & 45,11 & 60,63 & 65,31 & 47,96 & 74,38 \\
\hline Estonia & 48,69 & 38,69 & 55,89 & 56,73 & 24,71 & 77,29 \\
\hline Finland & 56,67 & 39,64 & 72,21 & 63,11 & 42,13 & 72,12 \\
\hline France & 37,46 & 30,63 & 44,26 & 44,57 & 25,91 & 45,80 \\
\hline Germany & 41,08 & 35,70 & 51,26 & 48,66 & 28,48 & 42,31 \\
\hline Greece & 26,13 & 18,93 & 34,21 & 32,67 & 24,27 & 20,62 \\
\hline Hungary & 31,69 & 29,40 & 38,44 & 46,03 & 17,95 & 28,21 \\
\hline Ireland & 43,07 & 26,29 & 47,46 & 41,49 & 46,29 & 61,01 \\
\hline Italy & 29,75 & 23,58 & 30,81 & 32,08 & 22,18 & 46,04 \\
\hline Latvia & 38,62 & 45,52 & 36,73 & 45,04 & 15,53 & 54,64 \\
\hline Lithuania & 40,37 & 34,33 & 34,94 & 48,15 & 33,68 & 60,65 \\
\hline Luxembourg & 44,77 & 45,10 & 52,57 & 58,22 & 26,90 & 41,58 \\
\hline Malta & 46,49 & 32,73 & 53,36 & 47,70 & 35,65 & 71,20 \\
\hline Netherlands & 51,23 & 40,37 & 54,33 & 59,55 & 43,38 & 66,31 \\
\hline Poland & 31,31 & 27,84 & 31,68 & 33,42 & 17,27 & 53,06 \\
\hline Portugal & 37,08 & 30,85 & 31,91 & 34,87 & 30,12 & 67,55 \\
\hline Romania & 26,87 & 34,94 & 27,47 & 21,71 & 16,73 & 31,11 \\
\hline Slovenia & 38,23 & 36,28 & 41,66 & 43,41 & 26,67 & 46,02 \\
\hline Slovakia & 33,06 & 28,88 & 36,97 & 42,78 & 27,95 & 30,60 \\
\hline Spain & 41,36 & 33,54 & 43,20 & 44,77 & 29,27 & 64,06 \\
\hline Sweden & 55,13 & 44,80 & 61,26 & 65,07 & 45,05 & 65,64 \\
\hline United Kingdom & 45,70 & 34,23 & 56,35 & 58,25 & 35,00 & 48,80 \\
\hline EU-28 & 38,91 & 31,13 & 43,99 & 45,01 & 29,22 & 50,21 \\
\hline
\end{tabular}

* Values rounded to two decimal places. Source: own study based on European Commission data available on the https://digital-agendadata.eu / (accessed on 23 October 2020). 
Table A2. DESI and its subcomponents in 2020 in a cross-section of EU-28 countries *.

\begin{tabular}{|c|c|c|c|c|c|c|}
\hline Country & DESI & Connectivity & Human Capital & $\begin{array}{l}\text { Use of Internet } \\
\text { Services }\end{array}$ & $\begin{array}{c}\text { Integration of Digital } \\
\text { Technology }\end{array}$ & $\begin{array}{c}\text { Digital Public } \\
\text { Services }\end{array}$ \\
\hline Austria & 54,31 & 47,15 & 56,73 & 54,02 & 40,58 & 80,84 \\
\hline Belgium & 58,71 & 52,03 & 50,39 & 61,16 & 65,87 & 71,73 \\
\hline Bulgaria & 36,44 & 38,50 & 33,92 & 36,65 & 17,86 & 61,76 \\
\hline Croatia & 47,56 & 41,15 & 49,15 & 55,48 & 41,47 & 55,75 \\
\hline Cyprus & 43,98 & 38,46 & 35,80 & 54,48 & 34,48 & 68,96 \\
\hline Czech Republic & 50,78 & 44,88 & 48,64 & 54,14 & 49,59 & 62,38 \\
\hline Denmark & 69,15 & 65,82 & 61,28 & 75,15 & 65,15 & 87,13 \\
\hline Estonia & 61,07 & 51,86 & 66,66 & 65,42 & 41,15 & 89,33 \\
\hline Finland & 72,31 & 59,17 & 78,44 & 76,34 & 67,05 & 86,99 \\
\hline France & 52,19 & 49,84 & 47,43 & 53,06 & 42,05 & 76,71 \\
\hline Germany & 56,05 & 59,40 & 56,42 & 61,57 & 39,53 & 66,37 \\
\hline Greece & 37,32 & 33,37 & 34,79 & 46,09 & 28,20 & 51,50 \\
\hline Hungary & 47,52 & 59,79 & 41,84 & 55,90 & 25,31 & 57,77 \\
\hline Ireland & 61,79 & 45,69 & 56,40 & 62,09 & 74,32 & 80,63 \\
\hline Italy & 43,65 & 49,99 & 32,46 & 44,48 & 31,23 & 67,48 \\
\hline Latvia & 50,71 & 61,76 & 35,02 & 53,98 & 28,31 & 85,06 \\
\hline Lithuania & 53,89 & 48,88 & 43,83 & 57,32 & 49,47 & 81,45 \\
\hline Luxembourg & 57,92 & 63,35 & 58,22 & 58,85 & 38,21 & 73,74 \\
\hline Malta & 62,70 & 58,72 & 61,76 & 65,90 & 54,90 & 78,13 \\
\hline Netherlands & 67,69 & 60,32 & 64,16 & 75,20 & 65,75 & 80,96 \\
\hline Poland & 44,96 & 51,34 & 37,27 & 49,64 & 26,24 & 67,41 \\
\hline Portugal & 49,58 & 53,92 & 37,77 & 48,09 & 40,87 & 75,12 \\
\hline Romania & 39,97 & 56,19 & 33,16 & 35,89 & 24,93 & 48,41 \\
\hline Slovenia & 51,20 & 50,23 & 48,35 & 51,71 & 40,95 & 70,75 \\
\hline Slovakia & 45,18 & 47,46 & 41,81 & 53,36 & 32,57 & 55,61 \\
\hline Spain & 57,54 & 60,79 & 47,56 & 60,78 & 41,22 & 87,28 \\
\hline Sweden & 69,74 & 64,37 & 71,72 & 75,95 & 62,13 & 79,34 \\
\hline United Kingdom & 60,41 & 48,82 & 63,00 & 73,31 & 54,19 & 70,77 \\
\hline EU-28 & 52,62 & 50,06 & 49,29 & 58,03 & 41,37 & 72,00 \\
\hline
\end{tabular}

* Values rounded to two decimal places. Source: own study based on European Commission data available on the https: / digital-agendadata.eu/ (accessed on 23 October 2020).

\section{References}

1. Iersel, J.P. Europe 2020 and the future of the European Union. Dans Eur. Format. 2011, 4, 147-168. [CrossRef]

2. Martens, W. Europe 2020 and beyond. Eur. View 2010, 9, 1-3. [CrossRef]

3. Hoedl, E. Europe 2020 strategy and European recovery. Probl. Sust. Dev. 2011, 6, 11-18.

4. Lundvall, B.A.; Lorenz, E. From the Lisbon strategy to Europe 2020. In Towards Social Investment Welfare State? Ideas, Policies and Challenges; Morel, N., Palier, B., Palme, J., Eds.; Policy Press: Bristol, UK, 2016; pp. 333-352.

5. Siuta-Tokarska, B.; Their, A.; Żmija, K. Procesy i Problemy w Realizacji Zrównoważonego i Trwałego Rozwoju w Polsce. Kontekst mikroekonomiczny (Processes and Problems in the Implementation of Sustainable Development in Poland. Microeconomic Context); PWN: Warszawa, Poland, 2019; pp. 11-28.

6. Portillo, A.F.; Gonzalez, M.A.; Mogollon, R.H. Impact of ICT development on economic growth. A study of OECD European union countries. Technol. Soc. 2020, 63. [CrossRef]

7. Das, A.; Khan, S.M. Effects of ICT development on economic growth in emerging Asian countries. In ICT in Developing Countries. Research, Practices and Policy Implications; Day, B., Sorour, K., Filieri, R., Eds.; Palgrave Macmillan: London, UK, 2016; pp. 141-159.

8. Day, B.; Ali, F. A critical review of the ICT for development research. In ICT in Developing Countries. Research, Practices and Policy Implications; Day, B., Sorour, K., Filieri, R., Eds.; Palgrave Macmillan: London, UK, 2016; pp. 3-23. 
9. Vicente, M.R.; Gil-de-Bernabe, F. Assessing the broadband gap: From the penetration divide to the quality divide. Technol. Forecast. Soc. Chang. 2010, 77, 816-822. [CrossRef]

10. Vicente, M.R.; Lopez, A.J. A multidimensional analysis of the disability digital divide: Some evidence for internet use. Inf. Soc. Int. J. 2010, 26, 48-64. [CrossRef]

11. Cilan, A.; Bolat, B.A.; Coskun, E. Analyzing digital divide within and between member and candidate countries of European Union. Gov. Inf. Q. 2009, 26, 98-105. [CrossRef]

12. Drożdż, W.; Miśkiewicz, R.; Pokrzywniak, J.; Elżanowski, F. Urban. Electromobility in the Context of Industry 4.0; Wydawnictwo Adam Marszałek: Torun, Poland, 2019.

13. Selvin, N.; Facer, K. Beyond the Digital Divide: Rethinking Digital Inclusion for the 21st Century; Futurelab: Bristol, UK, $2007 ; \mathrm{p} .40$.

14. Valenduc, G.; Vendramin, P. Work in the Digital Economy: Sorting the Old from the New; ETUI aisbl: Brussels, Belgium, 2016.

15. Servoz, M. AI. The Future of Work? Work of the Future! On How Artificial Intelligence, Robotics and Automation Are Transforming Jobs and the Economy in Europe; European Commission: Brussels, Belgium, 2019.

16. Brynjolfsson, E.; McAfee, A. Machine, Platform, Crowd: Harnessing Our Digital Future; W.W. Norton \& Company: New York, NY, USA, 2017.

17. Brooks, S.; Donovan, P.; Rumble, C. Developing nations. The digital divide and research databases. Ser. Rev. 2005, 31, 270-278. [CrossRef]

18. Qiang, C.Z.; Rossotto, C.M. Information and Communications for Development 2009: Extending Reach and Increasing Impact; World Bank: Washington, DC, USA, 2009; pp. 35-50.

19. Koutroumpis, P. The economic impact of broadband on growth: A simultaneous approach. Telecommun. Policy 2009, 33, 471-485. [CrossRef]

20. Czernich, N.; Falck, O.; Kretschmer, T.; Woessmann, L. Broadband infrastructure and economic growth. Econ. J. 2011, 121, 505-532 [CrossRef]

21. Kongaut, C.; Bohlin, E. Impact of broadband speed on economic outputs: An empirical study of OECD countries. In Proceedings of the 25th European Regional Conference of the International Telecommunications Society (ITS), Brussels, Belgium, $22-25$ June 2014.

22. Van Dijk, J.; Hacker, K. The digital divide as a complex and dynamic phenomenon. Inform. Soc. 2003, 19, 315-326. [CrossRef]

23. Cruz-Jesus, F.; Oliveira, T.; Bacao, F. Digital divide across the European Union. Inf. Manag. 2012, 4, 278-291. [CrossRef]

24. Fors, M.; Moreno, A. The benefits and obstacles of implementing ICT strategies for development from a bottom-up approach. Aslib Proc. 2002, 54, 198-206. [CrossRef]

25. Kuriyan, R.; Ray, I.; Toyama, K. Information communication technologies for development: The bottom of the pyramid model in practice. Inf. Soc. 2008, 24, 1-12. [CrossRef]

26. Mariscal, J. Digital divide in a developing country. Telecommun. Policy 2005, 29, 409-428. [CrossRef]

27. Parmar, V.; Keyson, D.; de Bont, C. International federation for information processing shaping social belief: A community sensitive health information system for rural India. In Home Informatics and Telematics: ICTs for the Next Billion; Venkatesh, A., Gonzalves, T., Monk, A., Buckner, K., Eds.; Springer: Boston, MA, USA, 2007; pp. 133-144.

28. Donner, J. Research approaches to mobile use in the developing world: A review of the literature. In Proceedings of the International Conference on Mobile Communication and Asian Modernities, Hong Kong, China, 7-8 June 2005.

29. Rashid, A.T.; Elder, L. Mobile phones and development: An analysis of IDRC-Upported projects. Electron. J. Inf. Syst. Dev. Ctries. 2009, 36, 1-16. [CrossRef]

30. Thapa, D.; Sæbø, Ø. Exploring the link between ICT and development in the context of developing countries: A literature review. Electron. J. Inf. Syst. Dev. Ctries. 2014, 64, 1-15. [CrossRef]

31. Van Dijk, J.A.G.M. The Evolution of the Digital Divide. The Digital Divide Turns to Inequality of Skills and Usage, Digital Enlightenment Yearbook; IOS Press: Amsterdam, The Netherlands, 2012; pp. 57-78.

32. Jabłoński, A.; Jabłoński, M. Social perspectives in digital business models of railway enterprises. Energies 2020, 13, 6445. [CrossRef]

33. Pelau, C.; Acatrinei, C. The paradox of energy consumption decrease in the transition period towards a digital society. Energies 2019, 12, 1428. [CrossRef]

34. Chen, S.; Zhou, M. Evolving container to Unikernel for edge computing and applications in process industry. Processes 2021, 9, 351. [CrossRef]

35. Kling, R.; Lamb, R. IT and organizational change in digital economies. In Understanding the Digital Economy; Brynjolfsson, E., Kahin, B., Eds.; MIT Press: Cambridge, MA, USA, 2000; pp. 295-324.

36. Dahlman, C.; Mealy, S.; Wermelinger, M. Harnessing the Digital Economy for Developing Countries; OECD: Paris, France, 2016.

37. Tapscott, D. The Digital Economy: Promise and Peril in the Age of Networked Intelligence; McGraw-Hill: New York, NY, USA, 1996.

38. Lane, N. Advancing the digital economy into the 21st century. Inf. Syst. Front. 1999, 1, 317-320. [CrossRef]

39. Brynjolfsson, E.; Kahin, B. (Eds.) Understanding the Digital Economy: Data, Tools, and Research; MIT Press: Cambridge, MA, USA, 2000.

40. Mesenbourg, T.L. Measuring the Digital Economy; US Bureau of the Census: Suitland, MD, USA, 2001.

41. Knickrehm, M.; Berthon, B.; Daugherty, P. Digital Disruption: The Growth Multiplier; Accenture: Dublin, Ireland, 2016.

42. Domazet, I.; Zubović, J.; Lazić, M. Driving factors of Serbian competitiveness: Digital economy and ICT. Strateg. Manag. 2018, 23, 20-28. [CrossRef]

43. Bukht, R.; Heeks, R. Defining, Conceptualising and Measuring the Digital Economy; University of Manchaster: Manchaster, UK, 2017; pp. 4-10. 
44. A Roadmap toward a Common Framework for Measuring the Digital Economy, Report for the G20 Digital Economy Task Force; OECD: Nejla Saula, Saudi Arabia, 2020.

45. Preparing the Future of Work We Want: The Digital Economy and Labour Skills and Competences. In Proceedings of the 19th American Regional Meeting, Panama City, Panama, 2-5 October 2018; International Labour Organization: Geneva, Switzerland, 2018. Available online: https://www.ilo.org/wcmsp5/groups/public/---ed_norm/---relconf/documents/meetingdocument/ wcms_644863.pdf (accessed on 5 January 2021).

46. The Digital Economy for Structural Change and Equality; ECLAC: Santiago, Chile, 2013.

47. Katzenbach, C.; Bächle, T.C. Defining concepts of the digital society. Internet Policy Rev. 2019, 8. [CrossRef]

48. Isin, E.; Ruppert, E. Being Digital Citizens; Rowman \& Littlefield Publishers: London, UK, 2015.

49. Sandulescu Budea, A.M. An approximation in the study of communication research: Digital evolution and the study of this subject in spanish academic journals. In Improving University Reputation through Academic Digital Branding; Del Pino, A.D., Romero, N.L., Eds.; IGI Global: Hershey, PA, USA, 2021.

50. Finos, R. 2016-2026 Worldwide Big Market Forecast, Wikibon 2016. Available online: https://wikibon.com/2016-2026worldwide-big-data-market-forecast/ (accessed on 5 January 2021).

51. Efimova, A.; Ruchkina, M.O.; Tereshina, O.Y. Transformation of the energy sector in conditions of digital economy. Light Eng. 2018, 26, 69-75.

52. Vlasov, A.I.; Shakhnov, V.A.; Filin, S.S.; Krivoshein, A.I. Sustainable energy systems in the digital economy: Concept of smart machines. Entrep. Sustain. Issues 2019, 6, 1975-1986. [CrossRef]

53. Avdeeva, E.; Davydova, T.; Belyantseva, O.; Makeeva, T. Factors of Sustainable Development of Energy Technologies in the Formation of Digital Economy. In Proceedings of the E3S Web Conference "Topical Problems of Green Architecture, Civil and Environmental Engineering" (TPACEE 2019), Moscow, Russia, 19-22 November 2019. [CrossRef]

54. Morishita-Steffen, N.; Alberola, R.; Mougeot, B.; Vignali, E.; Wikström, C.; Montag, U.; Gastaud, E.; Lutz, B.; Hartmann, G.; Pfaffenbichler, F.X.; et al. Smarter together: Progressing smart data platforms in Lyon, Munich, and Vienna. Energies 2021, 14, 1075. [CrossRef]

55. Borowski, F. Innovative Processes in Managing an Enterprise from the Energy and Food Sector in the Era of Industry 4.0. Processes 2021, 9, 381. [CrossRef]

56. Balcerzak, A.P. Technological potential of European Economy. Proposition of measurement with application of multiple criteria decision analysis. Montenegrin J. Econ. 2016, 12, 7-17. [CrossRef]

57. Stanickova, M. Can the implementation of the Europe 2020 Strategy goals be efficient? The challenge for achieving social equality in the European Union. Equilibr. Q. J. Econ. Econ. Policy 2017, 12, 383-398. [CrossRef]

58. Europe 2020-A Strategy for Smart, Sustainable and Inclusive Growth; European Commission: Brussels, Belgium, 2010 ; p. 37.

59. A Digital Agenda for Europe; European Commission: Brussels, Belgium, 2010.

60. Francik, A.; Szczepańska-Woszczyna, K. Innowacje i Przedsiębiorczośc-Ujęcie Makro-i Mikroekonomiczne (Innovation and Entrepreneurship - A Macro- and Micro-Economic Perspective); Wyższa Szkoła Biznesu w Dąbrowie Górniczej: Dabrowa Górnicza, Poland, 2016.

61. Borowiecki, R.; Olesiński, Z.; Rzepka, A.; Hys, K. Development of teal organisations in Economy 4.0. An empirical research. Eur. Res. Stud. J. 2021, 24, 117-129. [CrossRef]

62. MEMO/10/200, Europejska Agencja Cyfrowa: Kluczowe Inicjatywy (European Digital Agenda: The Key Initiatives). Available online: https:/ / ec.europa.eu/commission/presscorner/detail/pl/MEMO_10_200 (accessed on 1 February 2021).

63. A Digital Single Market. Strategy for Europe; European Commission: Brussels, Belgium, 2015.

64. Report on the Safety and Liability Implications of Artificial Intelligence, the Internet of Things and Robotics; European Commission: Brussels, Belgium, 2020.

65. Europe's Moment: Repair and Prepare for the Next Generation; European Commission: Brussels, Belgium, 2020.

66. Beck, K.; Grodzicki, M. Konwergencja Realna i Synchronizacja Cykli Koniunkturalnych w Unii Europejskiej. Wymiar Strukturalny (Real Convergence and Synchronization of Business Cycles in the European Union. Structural Dimension); Wyd. Scholar: Warszawa, Poland, 2014; p. 10.

67. Iosifidis, P. Digital convergence: Challenges for European regulation. J. Eur. Inst. Commun. Cult. 2002, 9, 27-47. [CrossRef]

68. Kyriakidou, V.; Michalakelis, C.; Sphicopoulos, T. Digital divide gap convergence in Europe. Technol. Soc. 2011, 33, 265-270. [CrossRef]

69. Hsu, W.C.H.J.; Tsai, M.H.; Tzeng, G.H. Exploring the best strategy plan for improving the digital converegence by using a hybrid MADM model. Technol. Econ. Dev. Econ. 2018, 24, 164-198. [CrossRef]

70. Lindgren, S. Digital Media and Society; SAGE: London, UK, 2017.

71. Papacharissi, Z.A. A Private Sphere. Democracy in a Digital Age; Polity Press: Cambridge, MA, USA, 2010.

72. Fagerjord, A.; Storsul, T. Questioning convergence. In Ambivalence towards Convergence. Digitalization and Media Change; Storsul, T., Stuedahl, D., Eds.; Nordicom, University of Gothenburg: Gothenburg, Sweden, 2007; pp. 19-31.

73. Baldwin, T.F.; Stevens McVoy, D.; Steinfield, C. Convergence: Integrating Media, Information and Communication; Sage: London, UK, 1996.

74. Green Paper on Convergence of the Telecommunications, Media and Information Technology Sectors, and the Implications for RegulationTowards an Information Society Approach; European Commission: Brussels, Belgium, 1997.

75. Fagerjord, A. Reading-view(s)ing the Über-box: A critical view on a popular prediction. In Cybertext Yearbook 2001; Eskelinen, M., Koskimaa, R., Eds.; Publications of the Research Centre for Contemporary Culture, University of Jyväskylä: Jyväskylä, Finland, 2002. 
76. Jenkins, H. Convergence Culture: Where Old and New Media Collide; MIT Press: Cambridge, MA, USA, 2006.

77. Beyer, Y.; Enli, G.; Maasø, A.; Ytreberg, E. Small talk makes a big difference: Recent developments in interactive SMS-based TV. Television New Media 2007, 3. [CrossRef]

78. Picard, R. The Economics of Financing of Media Companies; Fortham University Press: New York, NY, USA, 2002.

79. Hoskins, C.; McFaiden, S.; Finn, A. Media Economics: Applying Economics to New and Traditional Media; Sage: London, UK, 2004.

80. Østergaard, B.S. Convergence: Legislative dilemmas. In Media Policy. Convergence, Concentration and Commerce; McQuail, D., Siune, K., Eds.; Sage: London, UK, 1998.

81. Cuilenburg, J.; Slaa, P. From media policy towards a national communications policy: Broadening the scope. Eur. J. Commun. 1993, 8, 149-176. [CrossRef]

82. Skogerbø, E. Konvergens Mellom Telekommunikasjon og Kringkasting. Kulturogmediepolitiske Utfordringer; TemaNord, Nordic Council of Ministers: Copenhagen, Denmark, 1997; p. 560.

83. Noveck, B.S. Thinking analogue about digital television? Bringing European content regulation into the information age. In Convergence in European Digital TV Regulation; Marsden, C., Verhulst, S., Eds.; Blackstone Press Limited: London, UK, 1999.

84. Mitrovic, D. Measuring the efficiency of digital converegence. Econ. Lett. 2020, 188, 1-3. [CrossRef]

85. Laitsou, E.; Kargas, A.; Varoutas, D. Digital competitiveness in the European Union era: The Greek case. Economies $2020,8,85$. [CrossRef]

86. Kotarba, M. Measuring digitalization-Key metrics. Found. Manag. 2017, 9, 123-138. [CrossRef]

87. Chaaben, N.; Faysal, M. Digital economic and social evolution of Tunisia. In Proceedings of the Management International Conference, Venice, Italy, 24-27 May 2017; pp. 393-404.

88. Ziemkiewicz, B.; Pietrzak, M. Digital economy in the old European Union Member States. In Proceedings of the 18th International Scientific Conference Globalization and Its Socio-Economic Consequences, Rajecke Teplice, Slovakia, 10-11 October 2018; pp. 2437-2444.

89. Digital Economy and Society Index (DESI) 2020, Methodological Note; European Commission: Brussels, Belgium, $2020 ;$ pp. 4-14.

90. Vidruska, R. The Digital Economy \& Society Index and Network Readiness Index: Performance of Latvia on European Union Arena. In Proceedings of the New Challenges of Economic and Business Development Conference, Riga, Latvia, 12-14 May 2016; University of Latvia: Riga, Latvia, 2016. Available online: https://www.academia.edu/27238130/The_Digital_Economy_and_ Society_Index_and_Network_Readiness_Index_performance_of_Latvia_on_European_Union_arena (accessed on 23 March 2021).

91. Nagy, S. Digital economy and society. A cross country comparison of Hungary and Ukraine. Вісник Національного Технічного Університету “ХарківськийПолітехнічний Інститут" (Економічні Науки) 2017, 46, 174-179.

92. Moroz, M. The level of development of the digital economy in Poland and selected european countries: A comparative analysis. Found. Manag. 2017, 9, 175-190. [CrossRef]

93. Balacescu, A.; Babucea, A.G. Use of the internet by the Romanian citizens. An empirical study of digital gaps between regions. Analele Univ. Constantin Brâncu Târgu Jiu Ser. Econ. 2018, 1, 81-88.

94. Cesnauske, J. Digital economy and society: Baltic states in the EU context. Econ. Cult. 2019, 16, 80-90. [CrossRef]

95. Stavytskyy, A.; Kharlamova, G.; Stoica, E.A. The analysis of the digital economy and society index in the EU. Balt. J. Eur. Stud. 2019, 9, 245-261. [CrossRef]

96. International Digital Economy and Society Index 2020; European Union: Brussels, Belgium, 2021; p. 6.

97. Soszyńska, E. Konwergencja technologiczna a potencjał społeczno-technologiczny krajów Unii Europejskiej (Technological convergence and socio-technological potential of European Union countries). Metod. Ilościowe Bad. Ekon. (Quant. Methods Econ. Res.) 2012, 18, 191-201.

98. Digital Economy and Society Index, Eurostat. Available online: https://digital-agenda-data.eu/datasets/desi/visualizations (accessed on 23 October 2020).

99. Everitt, B.S.; Landau, S.; Leese, M. Cluster Analysis; Oxford University Press: London, UK, 2001.

100. Ward, J.H., Jr. Hierarchical grouping to optimize an objective function. J. Am. Stat. Assoc. 1963, 58, 236-244. [CrossRef]

101. Stanisz, A. Przystępny kurs Statystyki z Zastosowaniem STATISTICA PL na Przykładach z Medycyny. Tom 3 pt.: Analizy Wielowymiarowe (An Accessible Course in Statistics Using STATISTICA PL with Examples from Medicine. Volume 3: Multivariate Analyses); StatSoft Polska Sp. z o.o.: Kraków, Poland, 2007.

102. Kaufman, L.; Rousseeuw, P.J. Finding Groups in Data: An Introduction to Cluster Analysis; Wiley: New York, NY, USA, 1990.

103. Bánhidi, Z.; Dobos, I.; Nemeslaki, A. What the overall digital economy and society index reveals: A statistical analysis of the DESI EU28 dimensions. Reg. Stat. 2020, 10, 42-62. [CrossRef]

104. Castells, M.; Himanen, P. The Information Society and the Welfare State: The Finnish Model; Oxford University Press: New York, NY, USA, 2002.

105. Grigorescu, A.; Pelinescu, E.; Ion, A.E.; Dutcas, M.F. Human capital in digital economy: An empirical analysis of central and eastern European countries from the European Union. Sustainability 2021, 13, 2020. [CrossRef]

106. Simicevic, V.; Zoroja, J.; Pejic Bach, M. Cluster analysis of interent usage in European countries. In Proceedings of the Annals of DAAAM for 2012 \& Proceedings of the 23rd International DAAAM Symposium “Intelligent Manufacturing \& Automation", Zadar, Croatia, 24-27 October 2012; Katalinic, B., Ed.; DAAAM International: Vienna, Austria, 2012; Volume 23, No.1. pp. 525-528.

107. Şchiopu, R. Business digitization in the European Union. Proc. Int. Conf. Bus. Excell. 2020, 14, 385-397. [CrossRef] 